\title{
Somatic stem cells and the origin of cancer
}

\author{
José A. Martínez-Climent, Enrique J. Andreu and Felipe Prosper \\ Division of Oncology. Center for Applied Medical Research University of Navarra. Pamplona. Spain.
}

\begin{abstract}
Most human cancers derive from a single cell targeted by genetic and epigenetic alterations that initiate malignant transformation. Progressively, these early cancer cells give rise to different generations of daughter cells that accumulate additional mutations, acting in concert to drive the full neoplastic phenotype $^{1,2}$. As we have currently deciphered many of the gene pathways disrupted in cancer, our knowledge about the nature of the normal cells susceptible to transformation upon mutation has remained more elusive.
\end{abstract}

Adult stem cells are those that show long-term replicative potential, together with the capacities of self-renewal and multi-lineage differentiation. These stem cell properties are tightly regulated in normal development, yet their alteration may be a critical issue for tumorigenesis. This concept has arisen from the striking degree of similarity noted between somatic stem cells and cancer cells, including the fundamental abilities to self-renew and differentiate. Given these shared attributes, it has been proposed that cancers are caused by transforming mutations occurring in tissue-specific stem cells ${ }^{3-9}$. This hypothesis has been functionally supported by the observation that among all cancer cells within a particular tumor, only a minute cell fraction has the exclusive potential to regenerate the entire tumor cell population ${ }^{3,10-13}$; these cells with stem-like properties have been termed cancer stem cells. Cancer stem cells can originate from mutation in normal somatic stem cells that deregulate their physiological programs. Alternatively, mutations may target more committed progenitor cells or even mature cells, which become reprogrammed to acquire stem-like functions ${ }^{14,15}$ In any case, mutated genes should promote expansion of stem/pro-

\footnotetext{
*Supported by an unrestricted educational grant from AstraZeneca.

Correspondence: J.A. Martínez Climent.

Division of Oncology.

Center of Applied Medical Research.

University of Navarra.

Pamplona. Spain.

E-mail: jamcliment@unav.es
}

genitor cells, thus increasing their predisposition to cancer development by expanding self-renewal and pluripotency over their normal tendency towards relative quiescency and proper differentiation.

Key words: cancer stem cells, cancer, leukemia, telomerase, micro-RNAS.

Martínez-Climent JA, Andreu EJ, Prosper F. Somatic stem cells and the origin of cancer. Clin Transl Oncol. 2006;8(9). 647-63.

The ability of the stem cells to produce progeny that expresses different mature phenotypes is called potential or plasticity. Pluripotent embryonic stem cells can give rise to all of the differentiated tissues of the body whereas multipotent somatic stem cells have the capacity to form many but not all different cell types. Some childhood tumors have provided a link between embryonic stem cells and cancer ${ }^{16-18}$. Both neuroblastoma (which arises from fetal neural crest cells of the sympathetic nervous system) and Wilms tumor (which arises from embryonic cells of the kidney) are caused by mutations occurring in embryonic stem cells, giving rise to tumors composed of a mixture of undifferentiated spindle cells, immature epithelial tubules and more differentiated cells. Similarly, teratocarcinomas are made up of a variety of differentiated cell types as well as of embryonic and fetal tissue cells ${ }^{18,19}$. Because these normal embryonic cells physiologically differentiate with age and eventually disappear, neuroblastoma, teratocarcinomas and Wilms tumors only affect to young children ${ }^{16-18,20}$. However, the majority of cancers occurring in adults are derived from multipotent or pluripotent (somatic) stem cells, some of which have been recently discovered. Here we review the role of the cancer stem cells identified in different hematopoietic and solid tumors, focusing on the molecular networks that govern their homeostatic programs. We will additionally address emerging new concepts and controversial issues of cancer stem cell biology. Last, the potential implica- 
tion of cancer stem cells in the development of lymphoid malignancies will be discussed.

\section{HEMATOPOIETIC STEM CELLS AS TARGETS OF TRANSFORMING MUTATION IN LEUKEMIA}

Early bone-marrow reconstitution experiments in immunocompromised mice revealed the existence of the hematopoietic stem cells (HSCs) ${ }^{21,22}$. Recently, many tissue-specific stem cells have been identified $^{23-27}$. Stem cells share the characteristics of unlimited self-renewal, which maintains or expands the stem-cell population, and multi-lineage differentiation, which generates and regenerates tissues ${ }^{27}$. Yet another defining characteristic of stem cells is their limited replication frequency (quiescence) compared to their more proliferative progreny ${ }^{28}$. Although initial evidence for the concept of cancer stem cells also came from early studies ${ }^{10,29-31}$. solid experimental analysis have demonstrated their existence only recently. Two pioneering reports showed that despite most of the tumor cells obtained from patient with acute myeloid leukemia (AML) were unable to proliferate extensively, a small subset were capable of transferring the leukemia to immunocompromised mice. These leukemia-initiating stem cells (LSCs) were prospectively identified as having a CD34+ CD38- phenotype, resembling normal HSC s ${ }^{11,32,33}$. By contrast, CD34+CD38+ leukemic cells were not able to propagate the leukemia. Notably, on each of the morphological and genetic subtypes of AML, only the CD34+CD38- cell population retained the capacity to transfer the leukemia in vivo ${ }^{32}$. These data indicate that AMLs exhibiting different stages of differentiation are originated from a common LSC that shares similar cell-surface markers with normal long-term HSCs. Subsequent studies have characterized in detail the phenotypes of normal HSCs and LSCs. Besides a CD34+CD38- phenotype, both lack expression of the lineage markers CD71 and HLA-DR ${ }^{32,33}$. Notably, LSCs also lack expression of CD90 and the stem cell factor receptor CD117 (c-Kit) whereas they had high expression of the interleukin-3-alpha receptor CD12334,35. However, despite a common immunophenotype, LSCs are not functionally homogeneous but instead, resembling the normal hematopoiesis, form a hierarchy of cells that differ in their self-renewal potential ${ }^{56}$. The similarities between HSCs and LSCs strongly suggest that HSCs are the source of LSCs when targeted by oncogenic mutations. Nevertheless, these mutations may also target progenitor cells that become de novo leukemia stem-like cells (fig. 1).

Additional evidence supports that AML is a progressive model of cancer resulting from mutations in HSCs and their progeny. The $t(8 ; 21)(\mathrm{q} 22 ; \mathrm{q} 22)$ is the most frequent chromosomal translocation in AML, resulting in a chimeric $A M L 1-E T O$ gene fusion. In HSCs isolated from patients with AML in complete remission, AML1-ETO transcripts were found in a fraction of normal bone marrow HSCs ${ }^{37}$. These cells did not show leukemic properties, and normally differentiated to myeloid and erythroid cells. Consequently, the $t(8 ; 21)$ occurred in normal HSCs suggesting that it was the additional mutations in a subset of HSCs or their progeny which led to leukemia development. A different experimental approach has investigated the transformation capacity of a variety of oncogenes involved in human leukemia when ectopically expressed into the different HSC compartments. Shortlived myeloid progenitors transduced with $M L L-E N L$ or MOZ-TIF2 oncogenic fusions generated AML with similar latencies and characteristics than those observed in long-term HSC models ${ }^{15,38}$. Notably, this observation was not expanded to $B C R-A B L$ or $M L L$ GAS7 gene fusions, which did not transformed committed murine hematopoietic progenitors ${ }^{38,39}$. According to these data, some but not all oncogenes are capable of mediate similar leukemic transformation in both HSCs and committed progenitors. More recently, Eguchi et al expressed the two variants of the TEL-TRKC fusion gene, which are found in leukemias and solid tumors, into the mouse stem cell compartment. Results showed that the leukemia form of TEL-TRKC enhanced hematopoietic stem cell renewal and originated leukemia whereas the solid tumor variant of TEL-TRKC elicited impairment of hematopoiesis but did not induce cancer ${ }^{40}$. Thus, related oncogenic fusion genes similarly expressed in stem cells may produce diverse cell type-specific developmental impacts. This interesting finding might explain the phenotypic diversity of human leukemia despite having identical chromosomal rearrangements. Functional studies have also been conducted in chronic myeloid leukemia (CML), a disease of HSCs that undergo hierarchical differentiation, thus resulting in a vast majority of differentiated CML blood cells, whereas a rare cell fraction resembling normal HSCs is responsible for disease maintenance. CML cells also have the potential to generate acute leukemias of myeloid and lymphoid lineage during the blast cri$\operatorname{sis}^{41,42}$. At the molecular level, CML is characterized by the $B C R-A B L$ oncogenic fusion, which can be detected through all lineages of differentiation of CML cells, including the CD34+ stem cell compartment, pointing out to this leukemia as a prototype of stem cell disorder ${ }^{41-44}$. However, recent studies have indicated that the granulocyte-macrophage progenitor cells from patients with CML in blast crisis presented self-renewal capacity, a cell compartment which normally has not this property ${ }^{45}$. These data suggest that despite $B C R-A B L$ fusion targets CD34+ stem cells and originate CML in chronic phase, progenitor cells are also responsible for leukemic transformation in the 


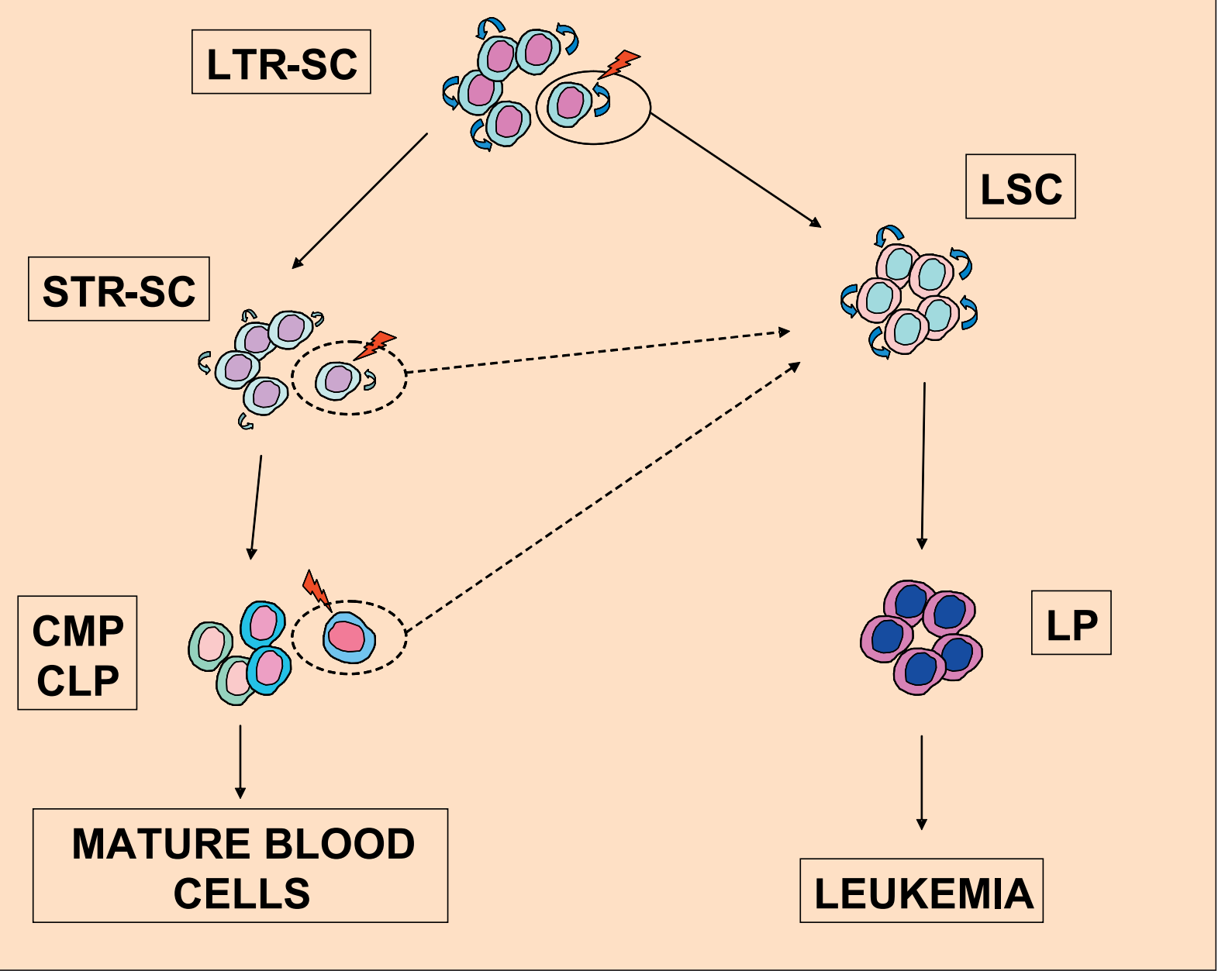

Fig. 1. Stem cells as targets of mutation in leukemia development. LTR-SC, Long-term repopulating stem cell; STR-SC, shortterm repopulating stem cell; CMP, common myeloid progenitors; CLP, common lymphoid progenitors; LSC, leukemia stem cell; LP, leukemia progenitors.

blast crisis, demonstrating that the hierarchy of leukemia-initiating stem cells can change during the progression of the disease.

In contrast to myeloid leukemia, progress towards the identification of the stem cell of origin in acute lymphoblastic leukemia (ALL) has been more limited. The best characterized leukemia subtype is ALL with $B C R-A B L$ chimeric protein (ALL-Ph+). Functional studies in a mouse model of ALL-Ph+ demonstrated that the only fraction of cells capable of engrafting NOD/SCID mice were CD34+/CD38- cells ${ }^{46}$. These data indicate that primitive progenitor cells rather than more committed lymphoid cells are targeted by $B C R-A B L$ gene rearrangement in ALL. A different study used human leukemic cells from patients with other subgroups of ALL ${ }^{47,48}$. ALL cells with a CD34+ CD10- phenotype were capable of transferring leukemia to NOD/SCID mice. The engrafted cells showed the same phenotype of the patients at diagnosis (CD34+,
CD10+, CD19+), indicating that CD34+ CD10- progenitor cells differentiated in vivo. Further functional characterization studies should determine whether multipotent HSCs or more committed progenitors are commonly targeted in the distinct ALL molecular subgroups or by contrast, specific ALL gene rearrangements occur in different stem cell populations.

\section{CANCER STEM CELLS AS THE ORIGIN OF SOLID TUMORS}

The leukemia experimental studies were subsequently extended to include epithelial cancers. Using a model of human breast cancer cells obtained from primary tumors and pleural metastatic effusions that were grown in non-obese diabetic, severe combined immunodeficient (NOD/SCID) mice, investigators distinguished the tumor-initiating cells from the nontumorigenic cells based on their cell phenotype ${ }^{12}$. 
Tumor-initiating cells expressed CD44 but little or no CD24. As few as 100 cells with this phenotype were able to form tumors in mice, whereas thousands of tumor cells with other different phenotypes failed. In addition, these cells could be serially passaged from mouse to mouse, and each time the new tumors contained the diverse mixed population of tumorigenic CD44+CD24-/low and non-tumorigenic cells present in the initial tumor ${ }^{12,49}$. The possibility to separate tumorigenic and non-tumorigenic cells will allow elucidating the molecular pathways that account for their different oncogenic potential.

The embryonic features present in several types of brain tumors have suggested that they originate from transformed neural stem or progenitor cells. The best example is childhood medulloblastoma, which is considered a failure of the process of differentiation of the neural primitive pluripotential cerebellum stem cells $^{18}$. In adult brain tumors, similar conclusions have been reached by three different groups ${ }^{50-52}$. Singh and colleagues prospectively identified a cell subpopulation from brain tumors expressing the human neural stem cell marker CD133 that exhibited stem cell properties in vitro and in vivo. These CD133+ cells were the only cell fraction capable of tumor initiation in NOD-SCID mouse ${ }^{13}$. Injection of as few as 100 cells with this phenotype generated tumors that were serially transplanted, whereas CD133- cells were unable to transfer the neoplasm. These cells were isolated from high and low grade tumors from both children and adults, suggesting that the principles of stem cell leukemogenesis may also be applied to the brain tumor pathogenesis. In contrast, Bachoo et al reported that not only neural stem cells but also mature neural cells (astrocytes) were equally capable of transformation upon INK4a and $A R F$ synergistic mutations ${ }^{14}$. These data support a different point of view where deregulation of specific genetic pathways, rather than cell-of-origin, dictates the emergence and phenotype of brain cancers ${ }^{53}$.

Recently, a mouse model in which expression of oncogenic K-ras is spatially and temporally controlled was used to study the stem cell of origin of lung cancer. Lox-K-ras mice developed atypical adenomatous hyperplasia that progressed to adenomas and then to adenocarcinomas $^{54}$. In Lox-K-ras tumors, a novel cell type expressing both the AT2 cell-specific marker SP$\mathrm{C}$ and the Clara cell-specific marker CCA, termed double-positive cells, were identified in adenomas, particularly in lesions continuous with bronchiolar hyperplasia. The study of their counterpart cells in normal lung led to the identification of a regional pulmonary stem cell population, termed bronchioalveolar stem cells (BASCs), at the bronchioalveolar duct junction. BASCs exhibited self-renewal potential, were multipotent in clonal assays and most remarkably, expanded in response to oncogenic K-ras in cul- ture and in precursors of lung tumors in vivo ${ }^{55}$. These data point to BASCs as the putative cells of origin for lung adenocarcinoma.

In 2004, Houghton et al published a controversial study supporting that gastric cancer is originated not from epithelial cells of the stomach but from bone marrow-derived cells that are recruited after Helicobcter infection to repair the microbe-induced damage $^{56}$. These bone marrow cells progressed through metaplasia and dysplasia to ultimately form epithelial cancer. Although this report further supports the well-accepted concept that chronic inflammation fosters cancer development, the results indicate that gastric tumors might arise from visiting bone marrow cells rather than from the transformation of local tissue-specific cells. In fact, Helicobacter pylori infection causes malignant transformation of the gastric mucosa-associated lymphoid tissue (MALT), leading to the generation of MALT lymphoma through activation of $\mathrm{NF}-\kappa \mathrm{B}$ pathway ${ }^{57-61}$. However, because bone marrow cells can adopt the phenotype of other cells by spontaneous fusion, this might have been the originating cause of this model of gastric cancer $^{62}$. More evidence is needed to prove any of these hypotheses in gastric cancer and in other inflammatory neoplasias.

\section{ONCOGENE AND TUMOR SUPPRESSOR GENE NETWORKS REGULATE SOMATIC AND CANCER STEM CELLS}

\section{Disruption of critical self-renewal pathways}

Cancer can be primarily considered as an alteration of the stem cell self-renewal pathway. Thus, it is not surprising that several genes that control normal stem-cell self-renewal can cause cancer when deregulated by mutations. WNT signaling pathway regulates proliferation and self-renewal of different organs whereas activating mutations of WNT proteins have been identified in a variety of cancers ${ }^{63-65}$. Other signaling pathways involved in stem cell selfrenewal include Notch, Sonic hedgehog (Shh), phosphatidylinositol-3 kinase (PIK3), and Homeobox (HOX) and Polycomb families, all of which are deregulated in hematopoietic and epithelial tumors ${ }^{64,66-72}$. A crucial task for investigators is to search for genetic and functional similarities and differences between normal and cancer stem cell self-renewal pathways.

$B M I 1$ is a gene member of the Polycomb Group family that has been involved in cancer ${ }^{72}$. In mouse models, forced expression of BMI1 in lymphocytes provokes lymphoma ${ }^{73}$ whereas $B M I 1$ is amplified and over-expressed in human mantle cell lymphoma ${ }^{74}$ specially in Ki67+ proliferating cells ${ }^{75}$. BMI1 deletion in mice causes defects in hematopoiesis, neurological 
development and body growth ${ }^{76}$. BMI1 acts through repressing two cyclin-dependent kinase inhibitors, $P 16 / I N K 4 a$ and P14/ARF $F^{77}$. Two simultaneous reports showed that $B M I 1$ has an essential role in regulating the proliferation of both normal and leukemic stem cells ${ }^{78,79}$. In addition, $B M I 1$ is also required for the self-renewal of stem cells in the peripheral and central nervous system ${ }^{80}$. These studies demonstrate that BMI1 presents similar functions in cancer and normal stem cells, yet its altered expression in stem cells may lead to tumorigenesis through disruption of genes (INK4a and $A R F$ among others) that regulate cell cycle control, apoptosis and DNA repair pathways.

However, a recent study challenges this concept and supports the existence of genes or pathways that have different effects on normal and cancer stem cells. The tumor suppressor PTEN is a phosphatase that negatively regulates signaling through the PI3K pathway, inhibiting survival and proliferation ${ }^{81}$. Inactivation of $P T E N$ has been reported in many cancer types, including lymphoid and myeloid leukemias ${ }^{81-84}$. Mice with conditional deletion of PTEN gene in adult HSCs developed myeloproliferative disease within days that evolved to transplantable leukemia within weeks. In contrast, normal HSCs without PTEN were progressively depleted and were unable to stably reconstitute irradiated mice after transplantation ${ }^{85,86}$. Thus, PTEN inactivation leads to depletion of normal HSCs but promotes the generation and expansion of leukemiainitiating cells. Most importantly, authors also demonstrated the potential therapeutic application of the differences of PTEN function in normal and cancer stem cells ${ }^{85}$. In PTEN deficient mouse, the PI3K pathway is constitutively activated, which in turn activates the mammalian target of rapamycin (mTOR). The drug rapamycin inhibits mTOR kinase activity ${ }^{87-89}$. In the PTEN-deficient mice, rapamycin depleted leukemia-initiating cells and rescued the capacity of normal HSCs to provide long-term multilineage reconstitution to irradiated mice.

\section{Telomerase activity and telomere length regulate cancer stem cells}

Normal human cells have two critical points that regulate their life span, the senescence and crisis phases. Senescence is associated with telomere shortening and cell cycle arrest. If cells bypass this stage, they keep growing until telomeres become critically short and cells enter crisis phase, characterized by chromosome instability and apoptosis ${ }^{90}$. To investigate the role of stem cells as targets for neoplastic transformation, adult human mesenchymal stem cells (hMSC) were transduced with the telomerase hTERT gene ${ }^{91}$. Long-term cultures of hMSC-TERT+ cells were characterized by progressive loss of contact inhibition, an- chorage independence and formation of tumors in immunodeficient mice. This transformation was associated with deletion of INK4a/ARF locus and KRAS activating mutation ${ }^{91,92}$. More recently, two independent groups have intriguingly reported the spontaneous malignant transformation of similar mesenchymal stem cells in vitro ${ }^{93,94}$. In one report, hMSCs isolated from adipose tissue bypassed senescence and crisis phases, after which $50 \%$ of the cells kept proliferating, acquired chromosome instability and were able of generating tumors in immunodeficient mice ${ }^{93}$. The spontaneous transformation was accompanied by loss of INK $4 a$ gene expression, $M Y C$ alteration and high telomerase activity. Similar findings were reported by Miura et al. using murine bone marrow-derived mesenchymal stem cells, which resulted in spontaneous fibrosarcoma formation ${ }^{94}$. The transformation process was also associated with chromosomal abnormalities involving $M Y C$ and upregulation of telomerase activity. The potential spontaneous transformation of somatic stem cells should deserve further attention because of their potential clinical use in tissue regenerative medicine.

In light of these previous reports, increased telomerase activity may be responsible, at least in part, for the malignant transformation of human and murine mesenchymal stem cells ${ }^{91-94}$. This finding is not totally unexpected, as alterations in telomere length and telomerase activity may facilitate cancer development by regulating genomic stability and cell lifespan ${ }^{95}$. In fact, a combination of shortened telomeres and increased telomerase activity is seen in most hematological and solid tumors ${ }^{96}$ and mTERT transgenic mice with increased telomerase activity spontaneously develop cancer ${ }^{97}$. The best model to study telomere functions in stem cells has been the hematopoietic cell compartment ${ }^{95,98}$. With age, HSCs lose telomeric DNA while maintaining detectable telomerase activity, what seems a mechanism to limit progressively the hematopoietic regeneration ${ }^{99}$. In fact, long-term repopulating capacity of telomerasedeficient murine HSCs is remarkably deficient ${ }^{100}$. Notably, these defects are not repaired by Tert overexpression in HSCs, indicating additional telomereindependent factors that regulate HSC regeneration $^{101}$. Together, these data point out to a role of telomeres in the regulation of HSC homeostasis ${ }^{102}$. Two recent studies investigated the effects of telomerase and telomere length on epidermal stem cell behaviour ${ }^{103,104}$. Using different constitutive and inducible transgenic mouse models, authors demonstrated that telomere length and telomerase activity are independent determinants of the mobilization efficiency and proliferative capacity of epidermal stem cells. Thus, telomere shortening inhibited mobilization of stem cells out of their niche and resulted in suppression of stem cell proliferation. In contrast, 


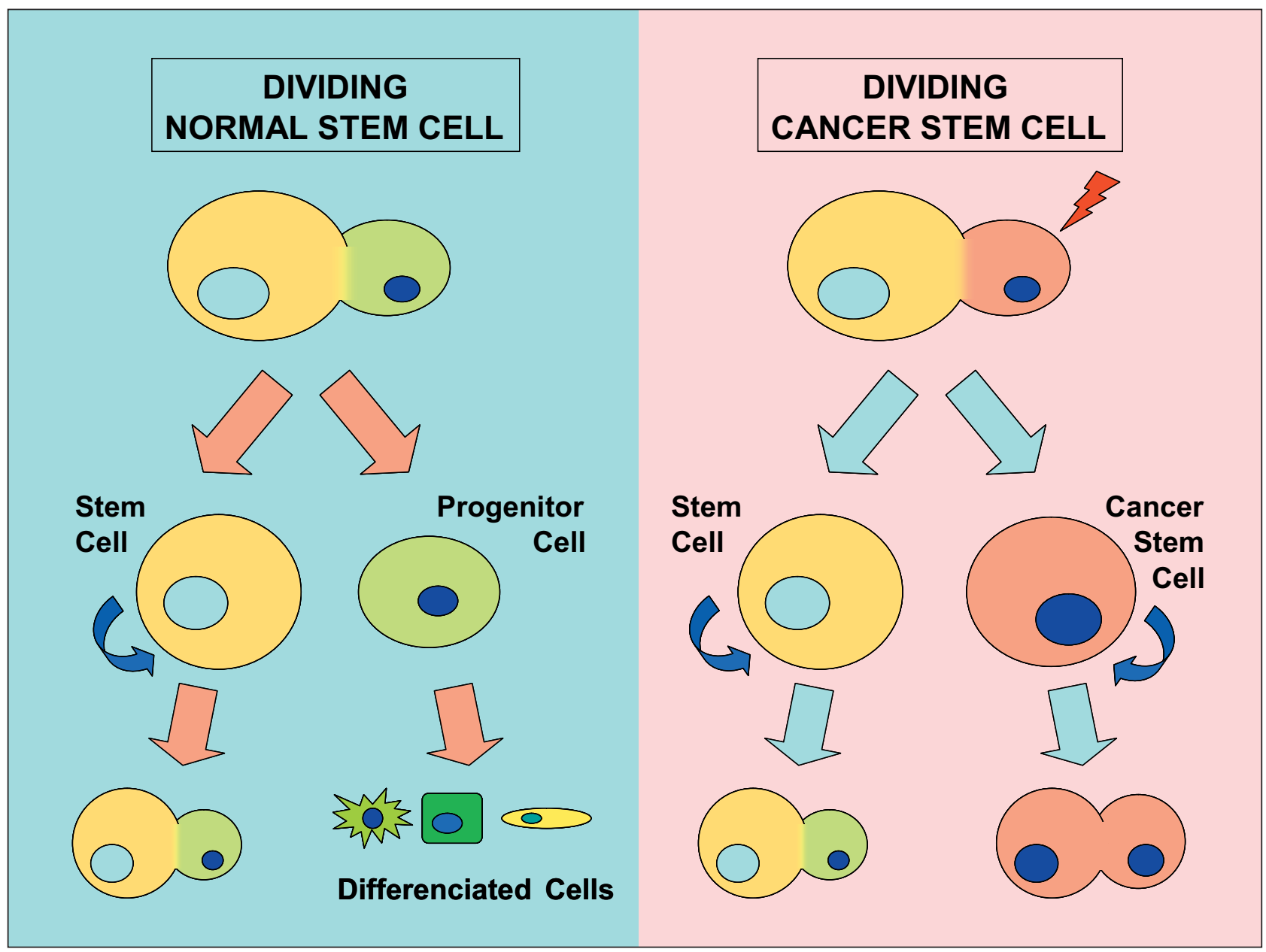

Fig. 2. Asymmetric and symmetric stem cell division modes occurring stem cells.

telomerase activation promoted stem cell mobilization and proliferation. These findings may explain the increased susceptibility of mTERT mice to develop skin tumors and anticipate a critical role of telomerase and telomere length in the regulation of cancer stem cells ${ }^{97,98,102}$.

\section{Asymmetric division of stem cells and cancer}

Stem cells fulfil their biological functions over the lifespan of the organism, thus requiring tight regulation of the self-renewal process. During early embryonic growth, stem cells divide symmetrically and each daughter cell retains the properties of the parental cell. The adult stem cells normally divide asymmetrically, whereby one daughter cell retains the properties of the parental stem cell and the other daughter cell begins differentiation ${ }^{105}$. But how can impairment of asymmetric division in stem cells lead to tumorigenesis? Drosophila melanogaster is an excellent model organism for the study of cancer development upon gene mutation ${ }^{71}$. One of the best characterized examples is neuroblastoma, a tumor originated from neuroblast stem cells. Normally, Drosophila neuroblasts divide asymmetrically, a process which is controlled by genes regulating cell polarity and cell fate $\mathrm{f}^{106,107}$. Using Drosophila as a model, three recent studies have shown that the loss of polarity and impairment of asymmetric division in stem cells leads to tumorigenesis ${ }^{108-110}$. In these reports, neuroblasts containing mutations in various genes that control cell division (Raps, Mira, Numb, Brat and Pros) developed aggressive tumors that could be retransplanted into new hosts. Importantly, asymmetric division was disrupted in mutant stem cells, whereby both daughter cells grow and behave like neuroblasts leading to the formation of tumors ${ }^{108-110}$. This transformation was associated with genome instability and centrosome alterations (fig. 2). Together, these data indicate that invertebrate cells rapidly develop cancer upon mutation of the asymmetric division machinery, by adopting an aberrant mode of symmetric division ${ }^{111}$.

Although there is no solid proof to link asymmetric cell division deregulation and human cancer, there are at least three examples that suggest this possibili- 
ty. The adenomatous polyposis coli $(A P C)$ gene is required for the asymmetric division of Drosophila spermatogonial stem cells and it is also a critical tumour suppressor in human colon cancer ${ }^{112-114}$. A human homologue of the Drosophila gene $L g L$ is HUGL1, which controls cell polarity and is commonly inactivated in cancer in humans and in mice ${ }^{115-117}$. Last, inactivation of Numb may in turn activate the Notch signalling pathway, commonly observed in human solid and hematopoietic tumors ${ }^{118,119}$. It may be hypothesized that APC mutations occurring in intestinal epithelial stem cells, HUGL1 or Numb alterations may lead to cancer by altering asymmetric cell division. The study of these and other human homologs of the Drosophila genes involved in the asymmetric/symmetric cell division switch may provide novel insights into human cancer development.

\section{Micro-RNAs as regulatory elements of cancer stem cells}

One of the key features of stem cells is their capacity to divide for long periods of time while being in a more quiescent state than their more proliferative progeny. For that, cell cycle must be critically controlled in stem cells. Recent studies have suggested a role of the microRNA pathway in the regulation of stem cell division ${ }^{120,121}$. MicroRNAs (miRNAs) are small noncoding RNAs that regulate expression of coding genes involved in the control of development, proliferation and apoptosis, primarily through translational repression ${ }^{122,123}$. Remarkably, miRNAs are deregulated by genomic alterations in cancer cells ${ }^{124,125}$, thus targeting oncogenes and suppressor genes in an aberrant manner ${ }^{126-129}$. One of the best characterized examples is the miRNA cluster miR-17-92 in the chromosome 13q31 amplicon, commonly observed in Bcell lymphoma and different carcinomas ${ }^{123,130,131}$. miR-17-92 over-expression appears to collaborate with $M Y C$ in promoting tumorigenesis ${ }^{127,128}$.

Initial evidence connecting miRNAs, stem cells and cancer was provided by Lu et al by classifying miRNA expression patterns in 334 primary tumors of different types and in normal tissues ${ }^{132}$. Notably, tumors displayed a miRNA profile that was reminiscent of that in the stem cells from which they were derived, providing a better indicator of tissue lineage that the conventional mRNA profiles. Overall, the expression level for most miRNAs was significantly reduced in the tumors while retaining expression of stem cell miRNAs, including the miR-17-92 cluster. One of the components of the miR-17-92 cluster, miR-19, has been shown to down-regulate the tumor suppressor PTEN $^{133}$. which is directly implicated in stem cell development ${ }^{85,86}$. It may be speculated that silencing of PTEN as a consequence of the miR-19 over-expression observed in many lymphomas and carcinomas may take place in tissue-specific stem cells, leading to cancer development. Another example was provided by Chen et al by showing that miR-181, which is preferentially expressed in bone marrow B-lymphoid cells, when ectopically expressed in hematopoietic stem or progenitor cells leads to an increased fraction of B-lineage that may ultimate cause malignancy ${ }^{134}$. A recent study provided additional links between miRNAs and the regulation of stem cells. The miR221 and miR-222 genes were shown to regulate CD34+ stem cell proliferation and differentiation by unblocking kit protein production at mRNA level, thus leading to eryhtroleukemia ${ }^{135}$. More direct evidence was provided by Hatfield et al, who deonstrated the necessity of the miRNA pathway for proper control of germline stem cell division in Drosophila $^{120}$. Analysis of these stem cells mutant for dicer1, the double-stranded RNaseIII essential for miRNA biogenesis, revealed a marked reduction in the rate of germline cyst production. These mutant stem cells were defective in cell cycle control by delaying the G1 to $S$ transition, thus making stem cells insensitive to stop signals ${ }^{120}$. If this miRNA machinery is mutated, it might contribute to tumor formation by promoting cell cycling and proliferation. Because silencing of miRNAs in vivo with "antagomirs» have been successfully used to treat disease in mouse models ${ }^{136}$. understanding the role of the miRNA pathway in the regulation of stem cell division may provide new opportunities for cancer treatment.

\section{Tumor progenitor genes and epigenetic origin of cancer}

It is widely accepted that cancer includes a heterogeneous group of disorders caused by a series of clonally selected genetic and epigenetic changes in oncogenes and tumor suppressor genes ${ }^{1,2}$. However, a recent theory suggests that cancer originates from a polyclonal epigenetic alteration of stem and progenitor cells within specific tissues, initially producing a pre-neoplastic epigenetically aberrant state ${ }^{137}$. Subsequently, an initiating mutation (specific activation of oncogenes in leukemia and sarcoma or inactivation of tumor suppressor genes in most solid tumors) targets a subpopulation of the epigenetically disrupted progenitor cells, thus leading to cancer development. A third stage would involve the acquisition of additional genetic and epigenetic changes that promote tumor progression and metastasis ${ }^{137}$. The epigenetic progenitor origin of human cancer hypothesis is based on several observations. First, epigenetic changes (global hypomethylation and specific gene promoter methylation) are detected early in tumorigenesis and what is more relevant, even in normal tissues before tumors arise ${ }^{138-140}$. Second, loss of genomic imprinting (parent-of-origin-specific gene si- 
lencing of a specific gene) is a different epigenetic mechanism that causes reduction or absence of expression of a specific allele of a gene in somatic cells of the offspring. Loss of imprinting (LOI) of the insuline-like growth factor 2 (IGF2) gene is observed in $50 \%$ of Wilms tumors and is associated with fivefold increased frequency of colorectal neoplasias ${ }^{141-144}$. Consequently, LOI of IGF2 might cause cancer by increasing the progenitor cell population in the kidney in Wilms tumor and in the gastrointestinal tract in colorectal cancer. According to this theory, authors define tumor-progenitor genes as those that suffer epigenetic modification in stem cells thus promoting malignant transformation ${ }^{137}$. Examples of these tumor progenitor genes are, in addition to IGF2, the POU transcription factor OCT4 or the forkhead transcription factor FOXD3, whose inappropriate expression could augment proliferation and block differentiation in stem cells ${ }^{145,146}$. One additional example may be represented by two DNA repair genes, ataxia teleangiectasia mutated (ATM) and checkpoint kinase 2 (CHK2), frequently inactivated in mantle cell lymphoma. This B-cell lymphoma is characterized by the chromosomal translocation $\mathrm{t}(11 ; 14)(\mathrm{q} 32 ; \mathrm{q} 21)$ that causes deregulation of cyclin D1 oncoprotein and is thought to be the earliest mutation in the disease ${ }^{147}$. In more than $50 \%$ of cases, genomic deletion or mutation of $A T M$ or $C H K 2$ genes accumulate to the initial $\mathrm{t}(11 ; 14)^{75,148,149}$. Notably, in a small subset of patients with mantle cell lymphoma, germline mutations of $A T M$ or CHK2 have been observed, indicating that this alterations preceded and may have conditioned the acquisition of the $t(11 ; 14)^{148,149}$. According to the epigenetics theory, ATM or CHK2 (and perhaps other DNA repair genes) might become silenced by epigenetic mechanisms (promoter hypermethylation, LOI) in a polyclonal stem or progenitor cell population. These stem/progenitor cells with damage of the DNA repair machinery would not control properly the physiological process of immunoglobulin gene rearrangement in early B-cells properly, thus causing aberrant chromosomal translocations that will promote lymphoma formation. Because the evidences supporting the epigenetic origin of cancer are still circumstantial, further experimental work will determine whether this interesting model is, at least in part, implicated in cancer development.

\section{THE STEM CELL NICHE AS A MASTER REGULATOR OF CANCER FORMATION}

Normal somatic and cancer stem cells not only share the capacities of self-renewal and multi-lineage differentiation, but are also similarly surrounded by a specialized cell microenvironment, termed the stem cell niche. The niche is the physical anchoring site for stem cells composed of cells that function to maintain and regulate stem cells homeostasis ${ }^{150}$. Adhesion molecules are also involved in the interaction between stem cells in their niche and the extracellular matrix. The niche regulates stem cell behaviour through providing extrinsic signals that balance stem cell proliferation, differentiation and symmetric/ asymmetric cell division. In addition, it has been proposed that the stem cell niche functions to prevent tumorigenesis by regulating self-renewal and proliferation rate in stem cells. Thus, intrinsic mutation in the niche may promote cancer development ${ }^{5,151}$. Furthermore, the molecular machinery used by normal stem cells for homing to or mobilizing from the niche may be utilized by cancer stem cells for invasion and metastasis $^{151}$.

Still, the idea of cancer as a consequence of stem cell niche mutations is hypothetical, although recent data support the role of the vascular niche in initiating metastasis ${ }^{152}$. In addition, skin tumors can be caused by telomerase activation, which promotes epidermal stem cell mobilization out of their niche together with increased cell proliferation ${ }^{97,103}$. The study of signalling pathways that control mobilization and homing of stem cells in the niche will enhance our understanding of cancer development, invasiveness, and metastasis. Furthermore, if cancer stem cells depend on their niche to survive, targeting the cell components of the niche may result in therapies that complement those targeting directly the cancer stem cells $^{150}$.

\section{DO LYMPHOID MALIGNANCIES ARISE FROM MUTATIONS THAT DEREGULATE SOMATIC STEM CELLS?}

In contrast to myeloid neoplasias, the identity of the stem cells responsible for the initiation and maintenance of lymphoid malignancies has not been resolved. Yet, lymphocyte lineage development, which follows a tightly regulated, hierarchical order which also permits a great flexibility, has been well characterized during the last years ${ }^{153-156}$. HSCs early differentiate to multipotent progenitors (MMP), which have lost long-term self-renewal capacity and are committed to either the lymphoid (common lymphoid progenitor or CLP) or myeloid (common myeloid progenitor or CMP) lineages. CLPs are restricted to lymphoid development, giving rise to B cells, T cells, dendritic cells and natural killer cells. These developmental steps are controlled by diverse cytokines and transcription factors cooperating to achieve efficient generation of mature lymphocytes ${ }^{154}$. In early stages, both PU.1 and Ikaros control the balance between myeloid or lymphoid commitment of MMPs through regulation of different signaling receptors (FLT3, cKIT and IL-7R) ${ }^{157-159}$. More committed, earliest B cell progenitor transition to pro-B cell depends on addi- 
tional transcription factors (E2A, EBF, PAX5 and BCL11A), which coordinately activate appropriate Bcell expression programs and immunoglobulin heavychain gene rearrangements ${ }^{160-165}$. (fig. 3). Alternatively, CLPs can differentiate to T-cells through Notch1 activation, which is negatively regulated by $\mathrm{PAX} 5^{166-168}$. Recent studies have shown the role of FOXP1 in the transition of pro-B cells to pre-B cells, a step which is also controlled by IRF4/MUM1 and IRF8 ${ }^{169,170}$. More differentiated B-cells are also tightly programmed by transcription factors. OBF1 and Aiolos are crucial for the transition of pre-B cells to immature B cells expressing BCR, as well as for the mobilization of immature B-cells from bone marrow to the spleen, whereas $\mathrm{NF}-\kappa \mathrm{B}$ activation has essential roles in the transition of immature to mature B-cells ${ }^{171-173}$. Additionally, BCL6, IRF4, BLIMP1, XBP1 and PAX5 are involved in the terminal differentiation of B-cells into plasma cells ${ }^{174-182}$.

Chromosomal translocations in lymphoid malignancies usually juxtapose the immunoglobulin or T-cell receptor genes with a variety of oncogenes which result deregulated ${ }^{183,184}$. Notably, many of the genes involved in the lymphocyte developmental network are targeted in such chromosomal translocations, namely PAX5, OBF1, BCL11A, BCL6, IRF4/MUM1, Ikaros, NOTCH1 and FOXP1 (table 1) $155,164,183,185-191$. Other regulatory genes are also altered through alternative genetic mechanisms, such as gene amplification of the $\mathrm{NF}-\kappa \mathrm{B}$ family gene REL, activating mutation of NOTCH1 and inactivating mutation of BLIMP1 119,192-194. Although these genetic rearrangements are thought to be early events in the lymphoma pathogenesis, transgenic mouse models for the lymphoma oncogenes have shown a great heterogeneity in driving malignancy in vivo. Thus, while mice with deregulated expression of $M Y C$ develop tumors displaying features typical of human Burkitt lymphoma, other models did not generate lymphoma spontaneously or developed tumors that did not resemble human disease $^{195-201}$. A possible explanation for the failure of this mouse models could be the necessity to express the aberrant oncogene into the adequate stem or progenitor cells to generate human-like lymphoma. Recent evidence supports this hypothesis. A transgenic mouse model where expression of BCL6 oncogene was restricted to the somatic stem cell compartment developed diffuse large B cell lymphoma that mimicked human disease (Pérez-Caro and SánchezGarcía, abstract AACR 2006). This lymphoma could only be propagated to secondary recipients by stem cells expressing BCL6. Moreover, gene expression patterns of stem cells expressing BCL6 showed a BCL6 signature and established a B-cell differentiation program. These results indicate that BCL6 oncogene is capable of driving a specific genetic program in stem cells that mediate their transformation into lymphoma cells. This concept is reinforced by NOTCH1, an essential regulator of $\mathrm{T}$ cell lineage development. More than 50\% of human T-cell acute lymphoblastic leukemias, including all major molecular oncogenic subtypes, have activating mutations of NOTCH1 gene ${ }^{119}$. Notably, constitutively activated forms of the NOTCH1 receptor are potent inducers of T cell acute lymphoblastic leukemia/lymphoma when expressed in murine bone marrow stem cells ${ }^{202}$. The mechanism by which NOTCH1 induces T-cell malignancy in stem cells appears to be an increase in their selfrenewal and proliferative properties ${ }^{202,203}$. Theoretically, other transcription factors controlling lymphocyte fate could, like BCL6 and NOTCH1, drive malignancy when mutated in stem cells.

Lineage commitment of lymphoid cells has been generally considered an irreversible process, but a recent challenging report by Xie et al. showed that enforced expression of $\mathrm{C} / \mathrm{EBP} \alpha / \beta$ transcription factors in differentiated B-cells leads to their reprogramming into macrophages by inhibiting PAX5 and synergizing with PU.1 ${ }^{204}$. This exceptional lymphoid plasticity might be also observed in lymphoma, as mutations in differentiated B or T cell lymphocytes may reprogram them into de novo stem-like cells. In support of this hypothesis, a recent report describes the mechanisms for B-cell lymphocyte reprogramming in malignan$\mathrm{cy}^{205}$. Hodgkin and Reed-Sternberg (HRS) cells, the tumor cells in classical Hodgkin lymphoma, derive from mature B cells but have largely lost their B-cell phenotype. This extensive reprogramming is experimentally caused by the inhibition of the transcription factor E2A in HRS cells ${ }^{205}$. These data conclude that the plasticity of mature human lymphoid cells upon mutation may contribute to cancer development. A different approach was used to investigate the cells of origin of multiple myeloma, a clonal B-cell neoplasm that affects terminally differentiated B cells (plasma cells $)^{206}$. Among the CD138+ myeloma plasma cells, a more immature and rare cell subpopulation that lacked CD138 expression was responsible for initiation and maintenance of the disease $\mathrm{e}^{29,207}$. These cells, which resembled post-germinal center B cells rather than fully differentiated plasma cells, may represent the cancer stem cells of origin of myeloma.

\section{CANCER STEM CELLS FROM A THERAPEUTIC PERSPECTIVE}

Hypothetically, conventional chemotherapy kills the rapidly proliferating tumor cells whereas cancer stem cells remain viable during treatment because of their relative quiescence ${ }^{208}$. Thus, when treatment ceases, cancer stem cells regenerate the tumor entirely, explaining why cancer can relapse in patients in complete remission $^{3,4,49}$. Consequently, destruction of the stem cell population capable of initiating and main- 


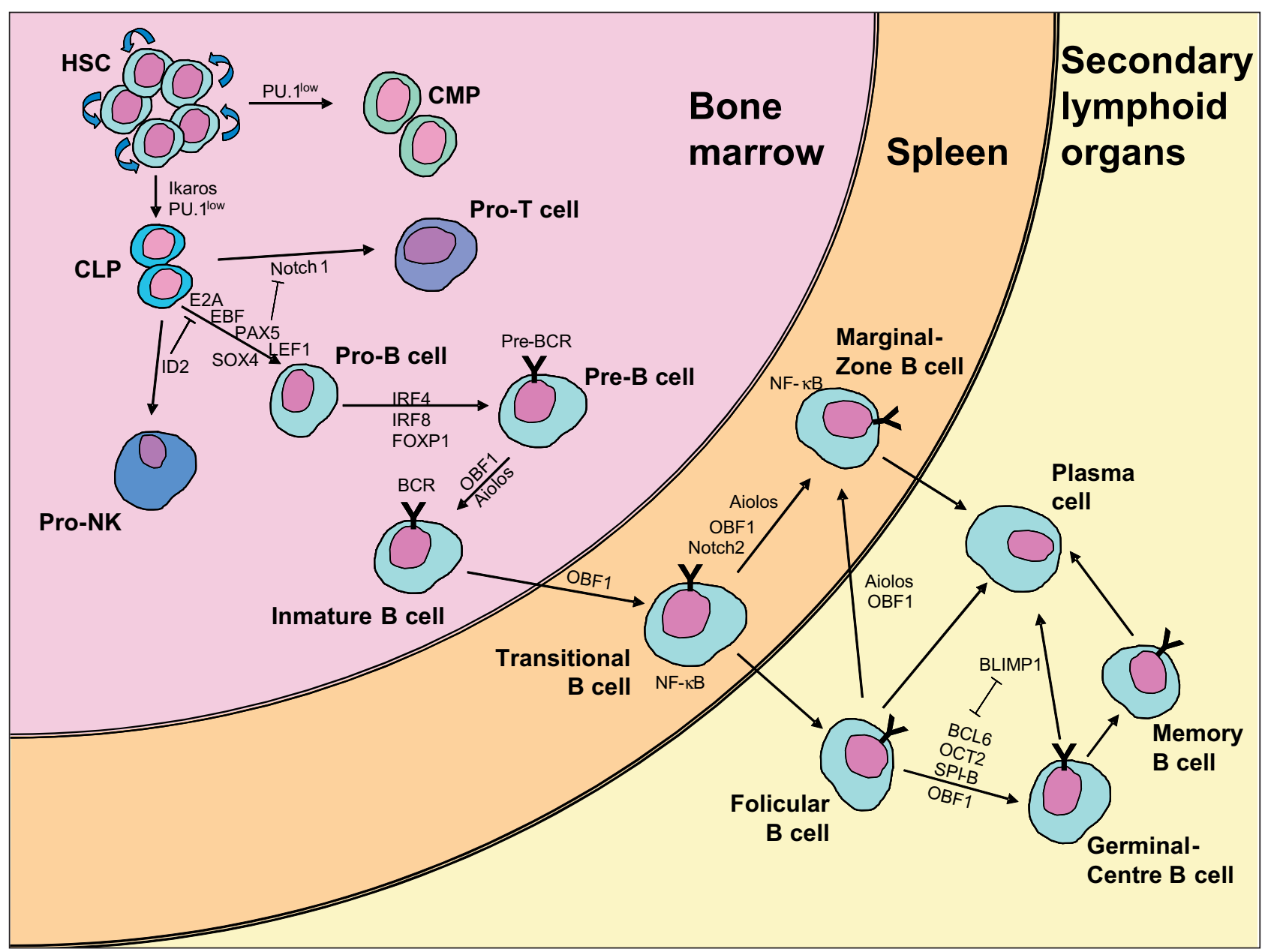

Fig. 3. Genetic control of B-cell lymphoid lineage developmental network in bone marrow, spleen and secondary lymphoid organs. Specific transcription factors that regulate each developmental stem are shown (for details, see text). HSC, hematopoietic stem cell; BCR, B-cell receptor; CLP, common lymphoid progenitor; CMP, common myeloid progenitor; pro-NK, pro-natural killer cell.

taining tumors challenges the treatment of human malignancies. But to date, there is only circumstantial evidence, and even contradictory, of this selective resistance of cancer stem cells to chemo- or radiotherapy. Normal tissue-specific stem cells, including HSCs, are more resistant to chemotherapy than mature cells from the same tissues. It can relate to the higher expression of drug-resistance proteins such as MDR1 and $\mathrm{ABC}$ transporters in stem cells, which might make them less sensitive to chemotherapy and apoptosis induction ${ }^{209,210}$. Supporting this concept, forced expression of the anti-apoptotic gene BCL2 in mouse hematopoietic stem cells makes them more resistant to radiotherapy ${ }^{211}$. A number of studies have evaluated that cancer stem cells, resembling normal stem cells, may be highly resistant to standard chemotherapy. Costello et al reported that CD34+CD38- AML stem cells presented reduced in vitro sensitivity to the chemotherapeutic agent daunorubicin compared to other AML cell populations and to normal HSCs as well $^{212}$. In contrast, Guzman and colleagues demonstrated that idarubicine (a daunorubicin analog) combined with the drug MG-132 selectively killed CD34+CD38- AML stem cells but not normal HSCs ${ }^{213}$. This apparently contradictory results may simply indicate that cancer stem cells are either sensitive or resistant to the different chemotherapeutic combinations. In fact, cancer stem cell sensitivity can also vary even with specific molecular-directed therapies. Imatinib, a potent tyrosine kinase inhibitor of the $B C R-A B L$ protein, has replaced interferon-alpha as the standard therapy of patients with $\mathrm{CML}^{214,215}$. However, ongoing clinical trials have not shown a clear survival benefit for the use of imatinib vs interpheron-alpha $^{216}$. Indeed, recent data suggest that imatinib may not achieve complete ablation of CML cells ${ }^{217}$, and even patients with CML who present complete molecular response almost invariably relapse when the drug is discontinued ${ }^{216,218}$. These observations may be explained by in vitro findings suggesting that ima- 


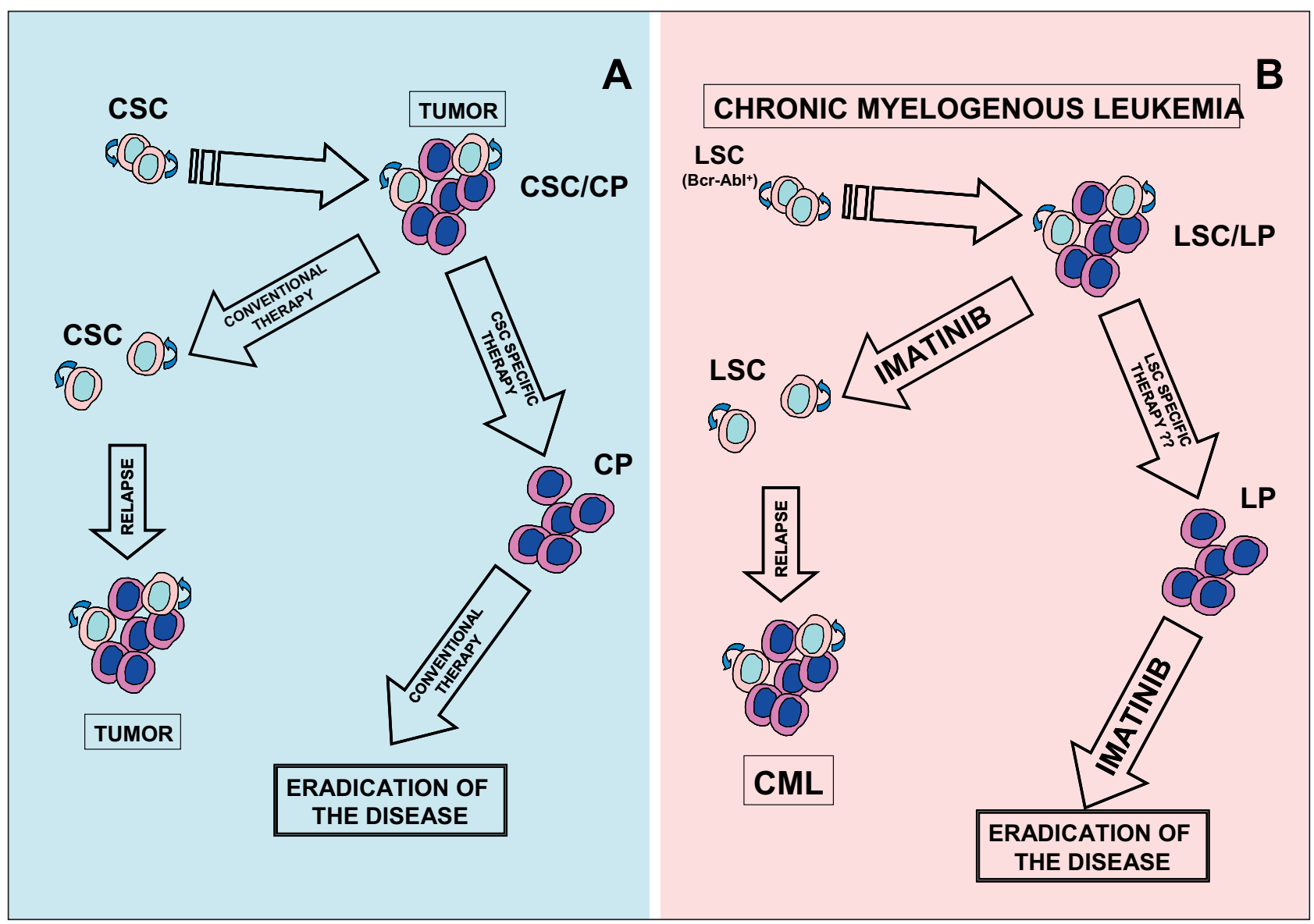

Fig. 4. Cancer stem cells and cancer treatment. A) Conventional therapies such as chemo or radiotherapy eradicate most tumor cells, including more committed cancer progenitor cells (CP) and differentiated cells, but may leave untouched the cancer stem cells (CSC). Thus, when therapy ceases, tumor arises from these remaining CSC. B) In chronic myeloid leukemia (CML), BCR-ABL+ hematopoietic stem cell generates the disease, which is composed of leukemic stem ells (LSC) and more committed leukemia progenitor cells (LP). Imatimib therapy seems to eradicate LP but not LSC, thus allowing leukemia relapse when treatment stops. Novel specific therapies that target BCR-ABL+ LSC are needed to ultimately eradicate the disease.

tinib, which is very active against differentiated CML progenitors, shows limited activity against CML stem cells $^{219-221}$. Unequivocal in vivo proof of the resistance of leukemic stem cells to imatinib was recently provided by Sanchez-Garcia et $\mathrm{al}^{222}$. A transgenic mouse model where expression of $B C R-A B L-\mathrm{p} 210$ was restricted to the somatic stem cell compartment led to development of CML that spontaneously evolved to blast crisis, thus mimicking human disease. Notably, imatinib treatment of these mice was not associated with clinical survival benefit, whereas CML stem cells expressing BCR-ABL were shown to be resistant in vivo to the drug (fig. 4). This mouse model may be useful not only to investigate imatinib responses in CML but also to test novel more potent $B C R-A B L$ tyrosine-kinase inhibitors ${ }^{223,224}$.

On the contrary, there are examples of successful eradication of cancer stem cells after targeting appropriate transforming mutated pathways ${ }^{85}$. As discussed above, PTEN inactivation in mice leads to de- pletion of normal HSCs but promotes the expansion of leukemia-initiating cells, thus leading to myeloid leukemia ${ }^{85,86}$. PTEN deficiency activates PI3K pathway, which in turn activates mTOR. Rapamycin is an active drug that inhibits mTOR kinase activity, and patients with acute leukemia respond to this drug $^{87,88}$. In the PTEN-deficient mice, rapamycin successfully eradicated leukemia by depleting leukemiainitiating cells and rescuing the capacity of normal HSCs to provide long-term multilineage reconstitution. A second molecular therapeutic target in leukemia is NOTCH1, which induces T-cell malignancy in stem cells by increasing their self-renewal and proliferative capacities, and is activated in more than half of the patients with T-cell ALL 119,202,203. Interestingly, inhibitors of the proteolytic enzyme $\gamma$-secretase are active in NOTCH1-mutated T-cell leukemia/lymphoma, and therapeutic clinical trials using this drug are now under development. Like these therapeutic agents (rapamycin, inhibitors of $\gamma$-secre- 


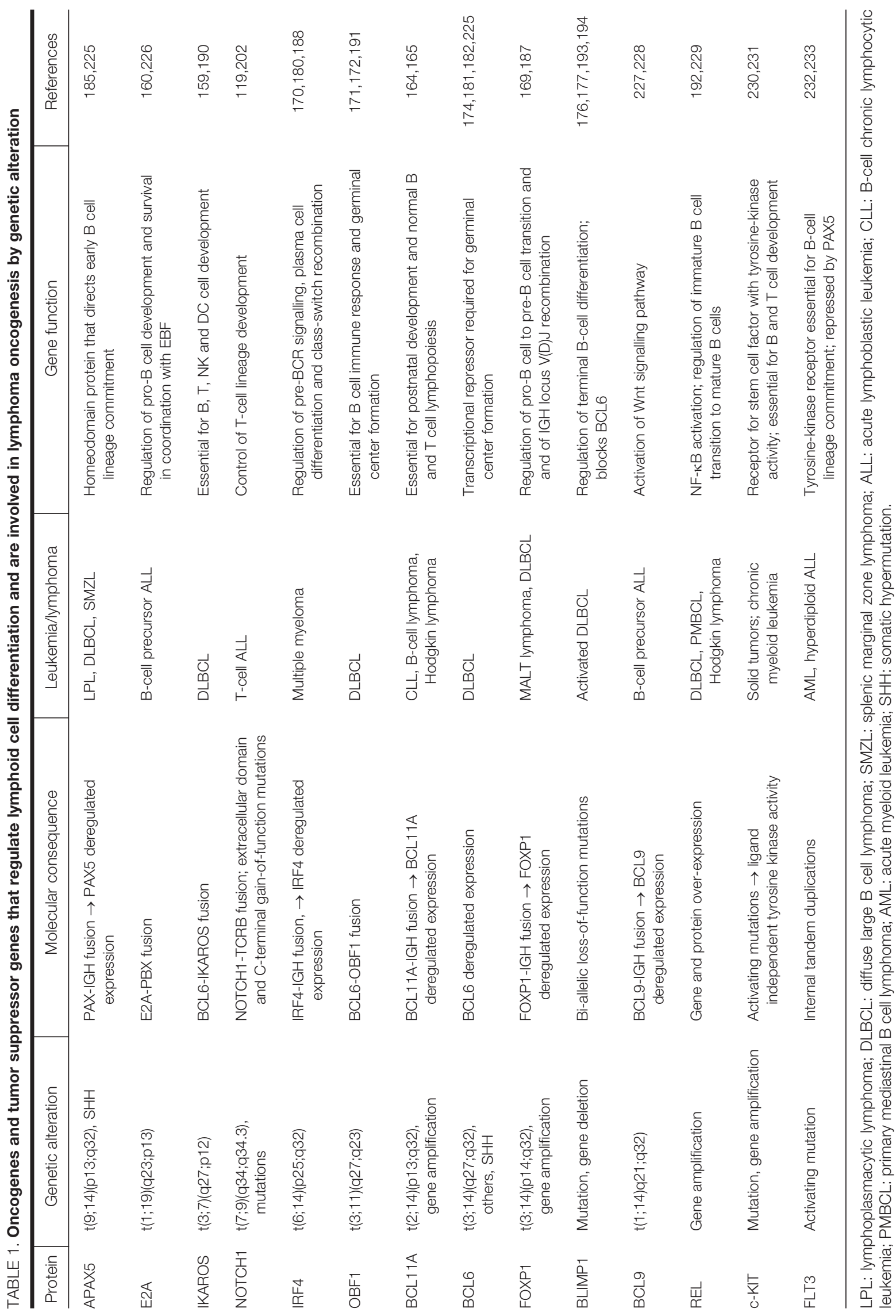


tase), to find other drugs that specifically target the defective pathways in cancer stem cells without damaging normal stem cells is a major goal in the battle against cancer.

\section{CONCLUSIONS}

The cancer stem cell hypothesis proposes that most cancers derive from tissue-specific stem cells or their immediate progeny through mutations that deregulate their self-renewal and differentiation pathways. Because stem cells are exposed to various tumorigenic agents throughout their lifetime, the ageing stem cell may represent a major target of malignant transformation. Solid demonstration of the existence of cancer stem cells has been shown in myeloid leukemia and in a subset of solid tumors, which represent a minority of human cancers. In addition, cancer stem cells have been defined by their functional capacity to form tumors in immunocompromised mice rather than by specific genetic studies. Detailed isolation and molecular characterization of all tissuespecific cancer stem cells should be a major task not only to better understand cancer biology but also to improve current treatments. Novel therapies should be designed to specifically target molecules or pathways damaged in cancer stem cells but not in normal cells. These efforts might result in higher cure rates for patients with cancer.

\section{References}

1 Hanahan D, Weinberg RA. The hallmarks of cancer. Cell. 2000;100:57-70.

2. Vogelstein B, Kinzler KW. Cancer genes and the pathways they control. Nat Med. 2004;10:789-99.

3. Reya T, Morrison SJ, Clarke MF, Weissman IL. Stem cells, cancer, and cancer stem cells. Nature. 2001;414:105-11.

4. Pardal R, Clarke MF, Morrison SJ. Applying the principles of stem-cell biology to cancer. Nat Rev Cancer. 2003;3:895-902.

5. Scadden DT. Cancer stem cells refined. Nat Immunol. 2004;5:701-3.

6. Bjerkvig R, Tysnes BB, Aboody KS, Najbauer J, Terzis AJ. Opinion: the origin of the cancer stem cell: current controversies and new insights. Nat Rev Cancer. 2005;5:899-904.

7. Polyak K, Hahn WC. Roots and stems: stem cells in cancer. Nat Med. 2006;12: 296-300.

8. Zhang M, Rosen JM. Stem cells in the etiology and treatment of cancer. Curr Opin Genet Dev. 2006;16:60-4.

9. Clarke MF, Fuller M. Stem cells and cancer: two faces of eve. Cell. 2006;124:1111-5.

10. Hamburger AW, Salmon SE. Primary bioassay of human tumor stem cells. Science. 1977;197:461-3.

11. Lapidot T, Sirard C, Vormoor J, et al. A cell initiating human acute myeloid leukaemia after transplantation into SCID mice. Nature. 1994;367:645-8

12. Al-Hajj M, Wicha MS, Benito-Hernández A, Morrison SJ, Clarke MF. Prospective identification of tumorigenic breast cancer cells. Proc Natl Acad Sci U S A. 2003 100:3983-8.

13. Singh SK, Hawkins C, Clarke ID, et al. Identification of human brain tumour initiating cells. Nature. 2004;432:396-401.

14. Bachoo RM, Maher EA, Ligon KL, et al. Epidermal growth factor receptor and Ink4a/Arf: convergent mechanisms governing terminal differentiation and transformation along the neural stem cell to astrocyte axis. Cancer Cell. 2002;1:269-77.

15. Cozzio A, Passegue E, Ayton PM, Karsunky H, Cleary ML, Weissman IL. Similar MLL-associated leukemias arising from self-renewing stem cells and short-lived myeloid progenitors. Genes Dev. 2003;17: 3029-35.

16. Beckwith JB, Palmer NF. Histopathology and prognosis of Wilms tumors: results from the First National Wilms' Tumor Study. Cancer. 1978;41:1937-48.
17. Shimada H, Chatten J, Newton WA, Jr., et al. Histopathologic prognostic factors in neuroblastic tumors: definition of subtypes of ganglioneuroblastoma and an age-linked classification of neuroblastomas. J Natl Cancer Inst. 1984;73:405-16.

18. Maris JM, Denny CT. Focus on embryonal malignancies. Cancer Cell. 2002;2:447 50.

19. O'Hare MJ. Teratomas, neoplasia and differentiation: a biological overview. I. The natural history of teratomas. Invest Cell Pathol. 1978;1:39-63.

20. Kim S, Chung DH. Pediatric solid malignancies: neuroblastoma and Wilms' tumor. Surg Clin North Am. 2006;86:469-87, xi.

21. Main JM, Prehn RT. Successful skin homografts after the administration of high dosage $X$ radiation and homologous bone marrow. J Natl Cancer Inst. 1955;15:1023-9.

22. Till JE, Mc CE. A direct measurement of the radiation sensitivity of normal mouse bone marrow cells. Radiat Res. 1961;14: 213-22.

23. Reynolds BA, Weiss S. Generation of neurons and astrocytes from isolated cells of the adult mammalian central nervous system. Science. 1992;255:1707-10.

24. Blanpain C, Lowry WE, Geoghegan A, Polak L, Fuchs E. Self-renewal, multipotency, and the existence of two cell populations within an epithelial stem cell niche. Cell. 2004;118:635-48.

25. Kordon EC, Smith GH An entire functional mammary gland may comprise the progeny from a single cell. Development. 1998;125:1921-30.

26. Jiang Y, Jahagirdar BN, Reinhardt RL, et al. Pluripotency of mesenchymal stem cells derived from adult marrow. Nature. 2002;418:41-9.

27. Eckfeldt CE, Mendenhall EM, Verfaillie CM. The molecular repertoire of the «almighty» stem cell. Nat Rev Mol Cell Biol. 2005;6:726-37.

28. Cheng T, Rodrigues N, Shen H, et al. Hematopoietic stem cell quiescence maintained by p21cip1/waf1. Science. 2000; 287:1804-8

29. Park CH, Bergsagel DE, McCulloch EA. Mouse myeloma tumor stem cells: a primary cell culture assay. J Natl Cancer Inst. 1971;46:411-22

30. Bruce WR, Van Der Gaag H. A Quantitative Assay For The Number of Murine Lymphoma Cells Capable Of Proliferation In Vivo. Nature. 1963;199:79-80.

31. Sabbath KD, Ball ED, Larcom $P$, Davis RB, Griffin JD. Heterogeneity of clono- genic cells in acute myeloblastic leukemia. J Clin Invest. 1985;75:746-53.

32. Bonnet D, Dick JE. Human acute myeloid leukemia is organized as a hierarchy that originates from a primitive hematopoietic cell. Nat Med. 1997;3:730-7.

33. Blair A, Hogge DE, Ailles LE, Lansdorp PM, Sutherland HJ. Lack of expression of Thy-1 (CD90) on acute myeloid leukemia cells with long-term proliferative ability in vitro and in vivo. Blood. 1997;89:3104-12.

34. Blair A, Sutherland HJ. Primitive acute myeloid leukemia cells with long-term proliferative ability in vitro and in vivo lack surface expression of c-kit (CD117). Exp Hematol. 2000;28:660-671.

35. Jordan CT, Upchurch D, Szilvassy SJ, et al. The interleukin-3 receptor alpha chain is a unique marker for human acute myelogenous leukemia stem cells. Leukemia. 2000;14:1777-84.

36. Hope KJ, Jin L, Dick JE. Acute myeloid leukemia originates from a hierarchy of eukemic stem cell classes that differ in self-renewal capacity. Nat Immunol. 2004; 5:738-43.

37. Miyamoto T, Weissman IL, Akashi K. AML1/ ETO-expressing nonleukemic stem cells in acute myelogenous leukemia with $8 ; 21$ chromosomal translocation. Proc Natl Acad Sci USA. 2000;97: 7521-6.

38. Huntly BJ, Shigematsu H, Deguchi K, et al. MOZ-TIF2, but not BCR-ABL, confers properties of leukemic stem cells to committed murine hematopoietic progenitors. Cancer Cell. 2004;6:587-96.

39. So CW, Karsunky H, Passegue E, Cozzio A, Weissman IL, Cleary ML. MLL-GAS7 transforms multipotent hematopoietic progenitors and induces mixed lineage leukemias in mice. Cancer Cell. 2003;3: 161-71.

40. Eguchi M, Eguchi-Ishimae M, Green A, Enver T, Greaves M. Directing oncogenic fusion genes into stem cells via an SCL enhancer. Proc Natl Acad Sci USA. 2005; 102:1133-8.

41. Sawyers CL. Chronic myeloid leukemia N Engl J Med. 1999;340:1330-40.

42. Goldman JM, Melo JV. Chronic myeloid leukemia--advances in biology and new approaches to treatment. N Engl J Med. 2003;349:1451-64.

43. Fialkow PJ, Jacobson RJ, Papayannopoulou T. Chronic myelocytic leukemia: clonal origin in a stem cell common to the granulocyte, erythrocyte, platelet and monocyte/macrophage. Am J Med. 1977; 63:125-30. 
44. Shtivelman E, Lifshitz B, Gale RP, Canaani E. Fused transcript of abl and bcr genes in chronic myelogenous leukaemia. Nature. 1985;315:550-4.

45. Jamieson CH, Ailles LE, Dylla SJ, et al. Granulocyte-macrophage progenitors as candidate leukemic stem cells in blastcrisis CML. N Engl J Med. 2004;351:65767.

46. Cobaleda C, Gutiérrez-Cianca N, PérezLosada J, et al. A primitive hematopoietic cell is the target for the leukemic transformation in human philadelphia-positive acute lymphoblastic leukemia. Blood. 2000;95:1007-13.

47. Cox CV, Evely RS, Oakhill A, Pamphilon DH, Goulden NJ, Blair A. Characterization of acute lymphoblastic leukemia progenitor cells. Blood. 2004;104:2919-25.

48. Blair A, Pamphilon DH. Leukaemic stem cells. Transfus Med. 2003;13:363-75.

49. Al-Hajj M, Clarke MF. Self-renewal and solid tumor stem cells. Oncogene. 2004; 23:7274-82.

50. Singh SK, Clarke ID, Terasaki M, et al. Identification of a cancer stem cell in human brain tumors. Cancer Res. 2003;63: 5821-8.

51. Hemmati HD, Nakano I, Lazareff JA, et al. Cancerous stem cells can arise from pediatric brain tumors. Proc Natl Acad Sci USA. 2003;100:15178-83.

52. Ignatova TN, Kukekov VG, Laywell ED, Suslov ON, Vrionis FD, Steindler DA. Human cortical glial tumors contain neural stem-like cells expressing astroglial and neuronal markers in vitro. Glia. 2002; 39:193-206.

53. Sanai N, Alvarez-Buylla A, Berger MS. Neural stem cells and the origin of gliomas. N Engl J Med. 2005;353:811-822.

54. Jackson EL, Willis N, Mercer K, et al Analysis of lung tumor initiation and progression using conditional expression of oncogenic K-ras. Genes Dev. 2001;15: 3243-8.

55. Kim CF, Jackson EL, Woolfenden AE, et al. Identification of bronchioalveolar stem cells in normal lung and lung cancer. Cell. 2005;121:823-35.

56. Houghton J, Stoicov C, Nomura S, et al. Gastric cancer originating from bone marrow-derived cells. Science. 2004;306: 1568-71.

57. Isaacson PG, Du MQ. MALT lymphoma: from morphology to molecules. Nat Rev Cancer. 2004:4:64:4-53.

58. Dierlamm J, Baens M, Wlodarska I, et al. The apoptosis inhibitor gene API2 and a novel $18 \mathrm{q}$ gene, MLT, are recurrently rearranged in the $\mathrm{t}(11 ; 18)(\mathrm{q} 21 ; \mathrm{q} 21)$ associated with mucosa-associated lymphoid tissue lymphomas. Blood. 1999;93:3601-9.

59. Willis TG, Jadayel DM, Du MQ, et al. Bcl10 is involved in $t(1 ; 14)(p 22 ; q 32)$ of MALT B cell lymphoma and mutated in multiple tumor types. Cell. 1999;96:35-45.

60. Zhang Q, Siebert R, Yan M, et al. Inactivating mutations and overexpression of BCL10, a caspase recruitment domain-containing gene, in MALT lymphoma with $\mathrm{t}(1 ; 14)(\mathrm{p} 22 ; \mathrm{q} 32)$. Nat Genet. 1999;22:63-8.

61. Sanchez-Izquierdo D, Buchonnet G, Siebert R, et al. MALT1 is deregulated by both chromosomal translocation and amplification in B-cell non-Hodgkin lymphoma. Blood. 2003;101:4539-46.

62. Terada N, Hamazaki T, Oka M, et al. Bone marrow cells adopt the phenotype of other cells by spontaneous cell fusion. $\mathrm{Na}-$ ture. $2002 ; 416: 542-5$.
63. Reya T, O'Riordan M, Okamura R, et al. Wnt signaling regulates B lymphocyte proliferation through a LEF-1 dependent mechanism. Immunity. 2000;13:15-24.

64. Taipale J, Beachy PA. The Hedgehog and Wnt signalling pathways in cancer. Nature. $2001 ; 411: 349-54$.

65. Reya T, Duncan AW, Ailles L, et al. A role for Wnt signalling in self-renewal of haematopoietic stem cells. Nature. 2003; 423:409-14.

66. Varnum-Finney B, Xu L, Brashem-Stein C, et al. Pluripotent, cytokine-dependent, hematopoietic stem cells are immortalized by constitutive Notch1 signaling. Nat Med. 2000;6:1278-81.

67. Bhardwaj G, Murdoch B, Wu D, et al. Sonic hedgehog induces the proliferation of primitive human hematopoietic cells via BMP regulation. Nat Immunol. 2001; 2:172-80.

68. Ohishi K, Katayama N, Shiku H, VarnumFinney B, Bernstein ID. Notch signalling in hematopoiesis. Semin Cell Dev Biol. 2003;14:143-50.

69. Abramovich C, Pineault N, Ohta H, Humphries RK. Hox genes: from leukemia to hematopoietic stem cell expansion. Ann N Y Acad Sci. 2005;1044:109-16.

70. Martelli AM, Nyakern M, Tabellini G, et al. Phosphoinositide 3-kinase/Akt signaling pathway and its therapeutical implications for human acute myeloid leukemia. Leukemia. 2006;20:911-28.

71. Ferres-Marco D, Gutiérrez-García I, Vallejo DM, Bolivar J, Gutiérrez-Avino FJ, Domínguez M. Epigenetic silencers and Notch collaborate to promote malignant tumours by Rb silencing. Nature. 2006; 439:430-6.

72. Raaphorst FM. Deregulated expression of Polycomb-group oncogenes in human malignant lymphomas and epithelial tumors. Hum Mol Genet. 2005;14 Spec 1:R93-R100.

73. Alkema MJ, Jacobs H, van Lohuizen M, Berns A. Pertubation of B and T cell development and predisposition to lymphomagenesis in Emu Bmi1 transgenic mice require the Bmil RING finger. Oncogene. 1997;15:899-910.

74. Bea S, Tort F, Pinyol M, et al. BMI-1 gene amplification and overexpression in hematological malignancies occur mainly in mantle cell lymphomas. Cancer Res. 2001;61:2409-12.

75. Rubio-Moscardo F, Climent J, Siebert R, et al. Mantle-cell lymphoma genotypes identified with $\mathrm{CGH}$ to BAC microarrays define a leukemic subgroup of disease and predict patient outcome. Blood. 2005; 105:4445-54.

76. van der Lugt NM, Domen J, Linders K, et al. Posterior transformation, neurological abnormalities, and severe hematopoietic defects in mice with a targeted deletion of the bmi-1 proto-oncogene. Genes Dev. 1994:8:757-69.

77. Jacobs JJ, Kieboom K, Marino S, DePinho RA, van Lohuizen M. The oncogene and Polycomb-group gene bmi-1 regulates cell proliferation and senescence through the ink4a locus. Nature. 1999;397:164-8.

78. Lessard J, Sauvageau G. Bmi-1 determines the proliferative capacity of normal and leukaemic stem cells. Nature. 2003; 423:255-60.

79. Park IK, Qian D, Kiel M, et al. Bmi-1 is required for maintenance of adult self-renewing haematopoietic stem cells. Nature. 2003;423:302-5.

80. Molofsky AV, Pardal R, Iwashita T, Park IK, Clarke MF, Morrison SJ. Bmi-1 de- pendence distinguishes neural stem cell self-renewal from progenitor proliferation. Nature. 2003;425:962-7.

81. Di Cristofano A, Pandolfi PP. The multiple roles of PTEN in tumor suppression. Cell. 2000;100:387-90.

82. Dahia PL, Aguiar RC, Alberta J, et al. PTEN is inversely correlated with the cell survival factor Akt/PKB and is inactivated via multiple mechanismsin haematological malignancies. Hum Mol Genet. 1999; 8:185-93.

83. Román-Gómez J, Jiménez-Velasco A Castillejo JA, et al. Promoter hypermethylation of cancer-related genes: a strong independent prognostic factor in acute lymphoblastic leukemia. Blood. 2004, 104:2492-8.

84. Stiles B, Groszer M, Wang S, Jiao J, Wu H. PTENless means more. Dev Biol. 2004; 273:175-84.

85. Yilmaz OH, Valdez R, Theisen BK, et al Pten dependence distinguishes haematopoietic stem cells from leukaemia-initiating cells. Nature. 2006;441:475-82.

86. Zhang J, Grindley JC, Yin T, et al. PTEN maintains haematopoietic stem cells and acts in lineage choice and leukaemia prevention. Nature. 2006;441:518-22.

87. Majumder PK, Febbo PG, Bikoff R, et al. mTOR inhibition reverses Akt-dependent prostate intraepithelial neoplasia through regulation of apoptotic and HIF-1-dependent pathways. Nat Med. 2004;10:594 601.

88. Inoki K, Corradetti MN, Guan KL. Dysregulation of the TSC-mTOR pathway in human disease. Nat Genet. 2005;37:1924.

89. Recher C, Beyne-Rauzy O, Demur C, et al. Antileukemic activity of rapamycin in acute myeloid leukemia. Blood. 2005;105: 2527-34.

90. Chin L, Artandi SE, Shen Q, et al. p53 deficiency rescues the adverse effects of telomere loss and cooperates with telomere dysfunction to accelerate carcinogenesis. Cell. 1999;97:527-38.

91. Serakinci N, Guldberg P, Burns JS, et al. Adult human mesenchymal stem cell as a target for neoplastic transformation. Oncogene. 2004;23:5095-8.

92. Burns JS, Abdallah BM, Guldberg P, Rygaard J, Schroder HD, Kassem M. Tumorigenic heterogeneity in cancer stem cells evolved from long-term cultures of telomerase-immortalized human mesenchymal stem cells. Cancer Res. 2005;65:3126-35.

93. Rubio D, García-Castro J, Martín MC, et al. Spontaneous human adult stem cell transformation. Cancer Res. 2005;65: 3035-9.

94. Miura M, Miura Y, Padilla-Nash HM, et al. Accumulated chromosomal instability in murine bone marrow mesenchymal stem cells leads to malignant transformation. Stem Cells. 2006;24:1095-103.

95. Blasco MA. Telomerase beyond telomeres. Nat Rev Cancer. 2002;2:627-33.

96. Ohyashiki JH, Sashida G, Tauchi T, Ohyashiki K. Telomeres and telomerase in hematologic neoplasia. Oncogene. 2002;21:680-7.

97. González-Suarez E, Samper E, Ramírez A, et al. Increased epidermal tumors and increased skin wound healing in transgenic mice overexpressing the catalytic subunit of telomerase, mTERT, in basal keratinocytes. Embo J. 2001;20:2619-30.

98. Ju Z, Rudolph KL. Telomeres and telomerase in cancer stem cells. Eur J Cancer. 2006; 42:1197-203. 
99. Allsopp RC, Cheshier S, Weissman IL. Telomere shortening accompanies increased cell cycle activity during serial transplantation of hematopoietic stem cells. J Exp Med. 2001;193:917-24.

100. Allsopp RC, Morin GB, DePinho R, Harley $\mathrm{CB}$, Weissman IL. Telomerase is required to slow telomere shortening and extend replicative lifespan of HSCs during serial transplantation. Blood. 2003;102:517-20.

101. Allsopp RC, Morin GB, Horner JW, DePinho R, Harley CB, Weissman IL. Effect of TERT over-expression on the long-term transplantation capacity of hematopoietic stem cells. Nat Med. 2003; 9:369-71.

102. Flores I, Benetti R, Blasco MA. Telomerase regulation and stem cell behaviour. Curr Opin Cell Biol. 2006;18:254-60.

103. Flores I, Cayuela ML, Blasco MA. Effects of telomerase and telomere length on epidermal stem cell behavior. Science. 2005; 309:1253-6.

104. Sarin KY, Cheung P, Gilison D, et al. Conditional telomerase induction causes proliferation of hair follicle stem cells. Nature. 2005;436:1048-52.

105. Sherley JL. Asymmetric cell kinetics genes: the key to expansion of adult stem cells in culture. Stem Cells. 2002;20:56172 .

106. Bilder D. Epithelial polarity and proliferation control: links from the Drosophila neoplastic tumor suppressors. Genes Dev. 2004;18:1909-25.

107. Lee CY, Robinson KJ, Doe CO. Lgl, Pins and aPKC regulate neuroblast self-renewal versus differentiation. Nature. 2006; 439:594-8.

108. Caussinus E, González C. Induction of tumor growth by altered stem-cell asymmetric division in Drosophila melanogaster. Nat Genet. 2005;37:1125-9.

109. Lee CY, Wilkinson BD, Siegrist SE, Wharton RP, Doe CQ. Brat is a Miranda cargo protein that promotes neuronal differentiation and inhibits neuroblast selfrenewal. Dev Cell. 2006;10:441-9.

110. Betschinger J, Mechtler K, Knoblich JA. Asymmetric segregation of the tumor suppressor brat regulates self-renewal in Drosophila neural stem cells. Cell. 2006; 124:1241-53

111. Morrison SJ, Kimble J. Asymmetric and symmetric stem-cell divisions in development and cancer. Nature. 2006;441:106874 .

112. Yamashita YM, Jones DL, Fuller MT. Orientation of asymmetric stem cell division by the APC tumor suppressor and centrosome. Science. 2003;301:1547-50.

113. Groden J, Thliveris A, Samowitz W, et al. Identification and characterization of the familial adenomatous polyposis coli gene. Cell. 1991;66:589-600.

114. Kinzler KW, Nilbert MC, Su LK, et al. Identification of FAP locus genes from chromosome 5q21. Science. 1991;253:661-5.

115. Schimanski CC, Schmitz G, Kashyap A, et al. Reduced expression of Hugl-1, the human homologue of Drosophila tumour suppressor gene lgl, contributes to progression of colorectal cancer. Oncogene. 2005:24:3100-9.

116. Kuphal S, Wallner S, Schimanski CC, et al. Expression of Hugl-1 is strongly reduced in malignant melanoma. Oncogene. 2006;25:103-10.

117. Klezovitch O, Fernández TE, Tapscott SJ, Vasioukhin V. Loss of cell polarity causes severe brain dysplasia in Lgl1 knockout mice. Genes Dev. 2004;18:559-71.
118. Pece S, Serresi M, Santolini E, et al. Loss of negative regulation by Numb over Notch is relevant to human breast carcinogenesis. J Cell Biol. 2004;167:215-21.

119. Weng AP, Ferrando AA, Lee W, et al. Activating mutations of NOTCH1 in human $\mathrm{T}$ cell acute lymphoblastic leukemia. Science. 2004;306:269-71.

120. Hatfield SD, Shcherbata HR, Fischer KA, Nakahara K, Carthew RW, RuoholaBaker H. Stem cell division is regulated by the microRNA pathway. Nature. 2005 ; 435:974-8.

121. Shcherbata HR, Hatfield S, Ward EJ, Reynolds S, Fischer KA, Ruohola-Baker H. The MicroRNA pathway plays a regulatory role in stem cell division. Cell Cycle. 2006; 5:172-5.

122. Bartel DP. MicroRNAs: genomics, biogenesis, mechanism, and function. Cell. 2004 116:281-97.

123. Hammond SM. MicroRNAs as oncogenes. Curr Opin Genet Dev. 2006;16:4-9.

124. Calin GA, Dumitru CD, Shimizu M, et al. Frequent deletions and down-regulation of micro- RNA genes miR15 and miR16 at 13q14 in chronic lymphocytic leukemia. Proc Natl Acad Sci USA. 2002;99:15524-9.

125. Calin GA, Sevignani C, Dumitru CD, et al. Human microRNA genes are frequently located at fragile sites and genomic regions involved in cancers. Proc Natl Acad Sci USA. 2004:101:2999-3004.

126. Cimmino A, Calin GA, Fabbri M, et al. miR-15 and miR-16 induce apoptosis by targeting BCL2. Proc Natl Acad Sci USA. 2005;102:13944-9.

127. He L, Thomson JM, Hemann MT, et al. A microRNA polycistron as a potential human oncogene. Nature. 2005;435:828-33.

128. O'Donnell KA, Wentzel EA, Zeller KI, Dang CV, Mendell JT. c-Myc-regulated microRNAs modulate E2F1 expression. Nature. 2005;435:839-43.

129. Johnson SM, Grosshans H, Shingara J, et al. RAS is regulated by the let- $7 \mathrm{mi}-$ croRNA family. Cell. 2005;120:635-47.

130. Ota A, Tagawa H, Karnan S, et al. Identification and characterization of a novel gene, C13orf25, as a target for 13q31-q32 amplification in malignant lymphoma. Cancer Res. 2004;64:3087-95.

131. Tagawa H, Seto M. A microRNA cluster as a target of genomic amplification in malignant lymphoma. Leukemia. 2005;19:2013-6.

132. Lu J, Getz G, Miska EA, et al. MicroRNA expression profiles classify human cancers. Nature. 2005;435:834-8.

133. Lewis BP, Shih IH, Jones-Rhoades MW, Bartel DP, Burge CB. Prediction of mam malian microRNA targets. Cell. 2003;115: 787-98.

134. Chen CZ, Li L, Lodish HF, Bartel DP. MicroRNAs modulate hematopoietic lineage differentiation. Science. 2004;303:83-6.

135. Felli N, Fontana L, Pelosi E, et al. MicroRNAs 221 and 222 inhibit normal erythropoiesis and erythroleukemic cell growth via kit receptor down-modulation. Proc Natl Acad Sci USA. 2005;102:18081-6.

136. Krutzfeldt J, Rajewsky N, Braich R, et al. Silencing of microRNAs in vivo with «antagomirs». Nature. 2005;438:685-9.

137. Feinberg AP, Ohlsson R, Henikoff S. The epigenetic progenitor origin of human cancer. Nat Rev Genet. 2006;7:21-33.

138. Feinberg AP, Vogelstein B. Hypomethylation distinguishes genes of some human cancers from their normal counterparts. Nature. 1983;301:89-92.

139. Issa JP, Ottaviano YL, Celano P, Hamilton SR, Davidson NE, Baylin SB. Methylation of the oestrogen receptor CpG island links ageing and neoplasia in human colon. Nat Genet. 1994;7:536-40.

140. Crawford YG, Gauthier ML, Joubel A, et al. Histologically normal human mammary epithelia with silenced p16(INK4a) overexpress COX-2, promoting a premalignant program. Cancer Cell. 2004;5:26373.

141. Cui H, Cruz-Correa M, Giardiello FM, et al. Loss of IGF2 imprinting: a potential marker of colorectal cancer risk. Science. 2003;299:1753-5.

142. Sakatani T, Kaneda A, IacobuzioDonahue CA, et al. Loss of imprinting of Igf2 alters intestinal maturation and tumorigenesis in mice. Science. 2005;307: 1976-8.

143. Ravenel JD, Broman KW, Perlman EJ, et al. Loss of imprinting of insulin-like growth factor-II (IGF2) gene in distinguishing specific biologic subtypes of Wilms tumor. J Natl Cancer Inst. 2001; 93:1698-703.

144. Woodson K, Flood A, Green L, et al. Loss of insulin-like growth factor-II imprinting and the presence of screen-detected colorectal adenomas in women. $J$ Nat Cancer Inst. 2004;96:407-10.

145. Nichols J, Zevnik B, Anastassiadis K, et al. Formation of pluripotent stem cells in the mammalian embryo depends on the POU transcription factor Oct4. Cell. 1998;95: 379-91.

146. Hanna LA, Foreman RK, Tarasenko IA, Kessler DS, Labosky PA. Requirement for Foxd3 in maintaining pluripotent cells of the early mouse embryo. Genes Dev. 2002;16:2650-61.

147. Fernandez V, Hartmann E, Ott G, Campo E, Rosenwald A. Pathogenesis of mantlecell lymphoma: all oncogenic roads lead to dysregulation of cell cycle and DNA damage response pathways. J Clin Oncol. 2005;23:6364-9

148. Camacho E, HernÁndez L, HernÁndez S, et al. ATM gene inactivation in mantle cell lymphoma mainly occurs by truncating mutations and missense mutations involving the phosphatidylinositol-3 kinase domain and is associated with increasing numbers of chromosomal imbalances. Blood. 2002;99:238-44.

149. Tort F, HernÁndez S, Bea S, et al. CHK2 decreased protein expression and infrequent genetic alterations mainly occur in aggressive types of non-Hodgkin lymphomas. Blood. 2002;100:4602-8.

150. Scadden DT. The stem-cell niche as an entity of action. Nature. 2006;441:1075-9.

151. Li L, Neaves WB. Normal stem cells and cancer stem cells: the niche matters. Cancer Res. 2006;66:4553-7.

152. Kaplan RN, Riba RD, Zacharoulis S, et al. VEGFR1-positive haematopoietic bone marrow progenitors initiate the premetastatic niche. Nature. 2005;438:820-7.

153. Rolink AG, Schaniel C, Busslinger M, Nutt SL, Melchers F. Fidelity and infidelity in commitment to B-lymphocyte lineage development. Immunol Rev. 2000;175:104-11.

154. Busslinger M. Transcriptional control of early B cell development. Annu Rev Immunol. 2004;22:55-79.

155. Matthias P, Rolink AG. Transcriptional networks in developing and mature B cells. Nat Rev Immunol. 2005;5:497-508.

156. Medina KL, Singh H. Genetic networks that regulate B lymphopoiesis. Curr Opin Hematol. 2005;12:203-9.

157. Scott EW, Simon MC, Anastasi J, Singh H. Requirement of transcription factor PU.1 
in the development of multiple hematopoietic lineages. Science. 1994;265:1573-7.

158. DeKoter RP, Singh H. Regulation of B lymphocyte and macrophage development by graded expression of PU.1. Science. $2000 ; 288: 1439-41$

159. Georgopoulos K, Bigby M, Wang JH, et al. The Ikaros gene is required for the development of all lymphoid lineages. Cell 1994;79:143-56.

160. Bain G, Maandag EC, Izon DJ, et al. E2A proteins are required for proper $\mathrm{B}$ cell development and initiation of immunoglobulin gene rearrangements. Cell. 1994;79: 885-92.

161. Lin H, Grosschedl R. Failure of B-cell differentiation in mice lacking the transcription factor EBF. Nature. 1995;376:263-7.

162. Nutt SL, Heavey B, Rolink AG, Busslinger M. Commitment to the B-lymphoid lineage depends on the transcription factor Pax5. Nature. 1999;401:556-62.

163. Rolink AG, Nutt SL, Melchers F, Busslinger M. Long-term in vivo reconstitution of T-cell development by Pax5-deficient Bcell progenitors. Nature. 1999;401:603-6.

164. Satterwhite E, Sonoki T, Willis TG, et al. The BCL11 gene family: involvement of BCL11A in lymphoid malignancies. Blood. 2001;98:3413-20.

165. Liu P, Keller JR, Ortiz M, et al. Bcl11a is essential for normal lymphoid development. Nat Immunol. 2003;4:525-32.

166. Radtke F, Wilson A, Mancini SJ, MacDonald HR. Notch regulation of lymphocyte development and function. Nat Immunol. 2004;5:247-53.

167. Maier H, Ostraat R, Gao H, et al. Early B cell factor cooperates with Runx1 and mediates epigenetic changes associated with mb-1 transcription. Nat Immunol. 2004;5:1069-77.

168. Stier S, Cheng T, Dombkowski D, Carlesso $\mathrm{N}$, Scadden DT. Notch1 activation increases hematopoietic stem cell self-renewal in vivo and favors lymphoid over myeloid lineage outcome. Blood. 2002;99. 2369-78

169. Hu H, Wang B, Borde M, et al. Foxp1 is an essential transcriptional regulator of $\mathrm{B}$ cell development. Nat Immunol. 2006;7: 819-26.

170. Lu R, Medina KL, Lancki DW, Singh H IRF-4, 8 orchestrate the pre-B-to-B transition in lymphocyte development. Genes Dev. 2003;17:1703-8.

171. Kim U, Oin XF, Gong S, et al. The B-cellspecific transcription coactivator OCA$\mathrm{B} / \mathrm{OBF}-1 / \mathrm{Bob}-1$ is essential for norma production of immunoglobulin isotypes. Nature. 1996;383:542-7.

172. Schubart DB, Rolink A, Kosco-Vilbois MH, Botteri F, Matthias P. B-cell-specific coactivator OBF-1/OCA-B/Bob1 required for immune response and germinal centre formation. Nature. 1996;383:538-42.

173. Sha WC, Liou HC, Tuomanen EI, Baltimore D. Targeted disruption of the p50 subunit of NF-kappa B leads to multifoca defects in immune responses. Cell. 1995; 80:321-30.

174. Ye BH, Cattoretti G, Shen Q, et al. The BCL-6 proto-oncogene controls germinalcentre formation and Th2-type inflammation. Nat Genet. 1997;16:161-70.

175. Reimold AM, Iwakoshi NN, Manis J, et al. Plasma cell differentiation requires the transcription factor XBP-1. Nature. 2001, 412:300-7.

176. Shaffer AL, Lin KI, Kuo TC, et al. Blimp-1 orchestrates plasma cell differentiation by extinguishing the mature B cell gene ex- pression program. Immunity. 2002;17:51 62.

177. Shaffer AL, Shapiro-Shelef M, Iwakoshi $\mathrm{NN}$, et al. XBP1, downstream of Blimp-1, expands the secretory apparatus and other organelles, and increases protein synthesis in plasma cell differentiation. Immunity. 2004;21:81-93.

178. Tunyaplin C, Shaffer AL, Angelin-Duclos CD, Yu X, Staudt LM, Calame KL. Direct repression of prdm 1 by Bcl-6 inhibits plasmacytic differentiation. J Immunol. 2004:173:1158-65.

179. Gatto D, Pfister T, Jegerlehner A, Martin SW, Kopf M, Bachmann MF. Complement receptors regulate differentiation of bone marrow plasma cell precursors expressing transcription factors Blimp-1 and XBP-1. J Exp Med. 2005;201:993-1005.

180. Klein U, Casola S, Cattoretti G, et al Transcription factor IRF4 controls plasma cell differentiation and class-switch recombination. Nat Immunol. 2006;7:773-82.

181. Phan RT, Dalla-Favera R. The BCL6 proto-oncogene suppresses p53 expression in germinal-centre B cells. Nature. 2004;432: $635-9$

182. Phan RT, Saito M, Basso K, Niu H, DallaFavera R. BCL6 interacts with the transcription factor Miz-1 to suppress the cyclin-dependent kinase inhibitor p21 and cell cycle arrest in germinal center B cells. Nat Immunol. 2005;6:1054-60.

183. Willis TG, Dyer MJ. The role of immunoglobulin translocations in the pathogenesis of B-cell malignancies. Blood. 2000; 96:808-22.

184. Kuppers R, Dalla-Favera R. Mechanisms of chromosomal translocations in B cell lymphomas. Oncogene. 2001;20:5580-94.

185. Busslinger M, Klix N, Pfeffer P, Graninger PG, Kozmik Z. Deregulation of PAX-5 by translocation of the Emu enhancer of the IgH locus adjacent to two alternative PAX-5 promoters in a diffuse large-cell lymphoma. Proc Natl Acad Sci USA. 1996; 93:6129-34.

186. Lo Coco F, Ye BH, Lista F, et al. Rearrangements of the BCL6 gene in diffuse large cell non-Hodgkin's lymphoma. Blood. 1994;83:1757-9.

187. Streubel B, Vinatzer U, Lamprecht A, Raderer M, Chott A. T(3;14)(p14.1;q32) involving IGH and FOXP1 is a novel recurrent chromosomal aberration in MALT lymphoma. Leukemia. 2005;19:652-8.

188. Iida S, Rao PH, Butler M, et al. Deregulation of MUM1/IRF4 by chromosomal translocation in multiple myeloma. Na Genet. 1997;17:226-30.

189. Ellisen LW, Bird J, West DC, et al. TAN-1, the human homolog of the Drosophil notch gene, is broken by chromosomal translocations in $\mathrm{T}$ lymphoblastic neoplasms. Cell. 1991;66:649-61.

190. Hosokawa Y, Maeda Y, Ichinohasama R, Miura I, Taniwaki M, Seto M. The Ikaros gene, a central regulator of lymphoid differentiation, fuses to the BCL6 gene as a result of $\mathrm{t}(3 ; 7)(\mathrm{q} 27 ; \mathrm{p} 12)$ translocation in a patient with diffuse large B-cell lymphoma. Blood. 2000;95:2719-21.

191. Galieque Zouitina S, Quief S, Hildebrand $\mathrm{MP}$, et al. The B cell transcriptional coactivator BOB1/OBF1 gene fuses to the LAZ3/BCL6 gene by $\mathrm{t}(3 ; 11)(\mathrm{q} 27 ; \mathrm{q} 23.1)$ chromosomal translocation in a $\mathrm{B}$ cell leukemia line (Karpas 231). Leukemia. 1996;10:579-87.

192. Joos S, Otano-Joos MI, Ziegler S, et al. Primary mediastinal (thymic) B-cell lymphoma is characterized by gains of chro- mosomal material including 9p and amplification of the REL gene. Blood. 1996 87:1571-1578

193. Pasqualucci L, Compagno M, Houldsworth J, et al. Inactivation of the PRDM1/ BLIMP1 gene in diffuse large B cell lymphoma. J Exp Med. 2006;203:311-7.

194. Tam W, Gomez M, Chadburn A, Lee JW Chan WC, Knowles DM. Mutational analysis of PRDM1 indicates a tumor-suppressor role in diffuse large B-cell lymphomas. Blood. 2006;107:4090-100.

195. Baron BW, Anastasi J, Montag A, et al. The human BCL6 transgene promotes the development of lymphomas in the mouse. Proc Natl Acad Sci U S A. 2004:101:14198-203.

196. Adams JM, Harris AW, Pinkert CA, et al The c-myc oncogene driven by immunoglobulin enhancers induces lymphoid malignancy in transgenic mice. Nature. 1985;318:533-8

197. McDonnell TJ, Korsmeyer SJ. Progression from lymphoid hyperplasia to high-grade malignant lymphoma in mice transgenic for the $\mathrm{t}(14 ; 18)$. Nature. 1991;349:254-6.

198. Lovec H, Grzeschiczek A, Kowalski MB, Moroy T. Cyclin D1/bcl-1 cooperates with myc genes in the generation of B-cell lymphoma in transgenic mice. Embo J. 1994;13:3487-95.

199. Gladden AB, Woolery R, Aggarwal P, Wasik MA, Diehl JA. Expression of constitutively nuclear cyclin D1 in murine lymphocytes induces B-cell lymphoma. Oncogene. 2006;25:998-1007.

200. Souabni A, Cobaleda C, Schebesta M, Busslinger M. Pax5 promotes B lymphopoiesis and blocks $\mathrm{T}$ cell development by repressing Notch1. Immunity. 2002; 17:781-93.

201. Cattoretti G, Pasqualucci L, Ballon G, et al. Deregulated BCL6 expression recapitulates the pathogenesis of human diffuse large B cell lymphomas in mice. Cancer Cell. 2005;7:445-55.

202. Pear WS, Aster JC. T cell acute lymphoblastic leukemia/lymphoma: a human cancer commonly associated with aberrant NOTCH1 signaling. Curr Opin Hematol. 2004;11:426-33.

203. Huntly BJ, Gilliland DG. Leukaemia stem cells and the evolution of cancer-stem-cell research. Nat Rev Cancer. 2005;5:311-21.

204. Xie H, Ye M, Feng R, Graf T. Stepwise reprogramming of B cells into macrophages. Cell. 2004;117:663-76.

205. Mathas S, Janz M, Hummel F, et al. Intrinsic inhibition of transcription factor E2A by HLH proteins ABF-1 and Id 2 mediates reprogramming of neoplastic $\mathrm{B}$ cells in Hodgkin lymphoma. Nat Immunol. 2006; 7:207-15.

206. Mitsiades CS, Mitsiades N, Munshi NC, Anderson KC. Focus on multiple myeloma. Cancer Cell. 2004;6:439-44.

207. Matsui W, Huff CA, Wang Q, et al. Characterization of clonogenic multiple myeloma cells. Blood. 2004;103:2332-6.

208. Al-Hajj M, Becker MW, Wicha M, Weissman I, Clarke MF. Therapeutic implications of cancer stem cells. Curr Opin Genet Dev. 2004;14:43-7.

209. Chaudhary PM, Roninson IB. Expression and activity of P-glycoprotein, a multidrug efflux pump, in human hematopoietic stem cells. Cell. 1991;66:85-94.

210. Zhou S, Schuetz JD, Bunting KD, et al The ABC transporter Bcrp1/ABCG2 is expressed in a wide variety of stem cells and is a molecular determinant of the side-population phenotype. Nat Med. 2001;7:1028-34. 
211. Domen J, Gandy KL, Weissman IL. Systemic overexpression of BCL-2 in the hematopoietic system protects transgenic mice from the consequences of lethal irradiation. Blood. 1998;91:2272-82.

212. Costello RT, Mallet F, Gaugler B, et al. Human acute myeloid leukemia CD34+/ CD38- progenitor cells have decreased sensitivity to chemotherapy and Fas-induced apoptosis, reduced immunogenicity, and impaired dendritic cell transformation capacities. Cancer Res. 2000;60: 4403-11.

213. Guzman ML, Swiderski CF, Howard DS, et al. Preferential induction of apoptosis for primary human leukemic stem cells. Proc Natl Acad Sci U S A. 2002;99:16220-5.

214. Druker BJ, Tamura S, Buchdunger E, et al. Effects of a selective inhibitor of the Abl tyrosine kinase on the growth of BcrAbl positive cells. Nat Med. 1996;2:561-6.

215. O'Brien SG, Guilhot F, Larson RA, et al. Imatinib compared with interferon and low-dose cytarabine for newly diagnosed chronic-phase chronic myeloid leukemia. N Engl J Med. 2003;348:994-1004.

216. Huff CA, Matsui W, Smith BD, Jones RJ. The paradox of response and survival in cancer therapeutics. Blood. 2006;107:431-4.

217. Michor F, Hughes TP, Iwasa Y, et al. Dynamics of chronic myeloid leukaemia. Nature. 2005;435:1267-70.

218. Cortés J, O'Brien S, Kantarjian H. Discontinuation of imatinib therapy after achieving a molecular response. Blood. 2004; 104:2204-5.
219. Graham SM, Jorgensen HG, Allan E, et al. Primitive, quiescent, Philadelphia-positive stem cells from patients with chronic myeloid leukemia are insensitive to STI571 in vitro. Blood. 2002;99:319-25.

220. Holtz MS, Slovak ML, Zhang F, Sawyers CL, Forman SJ, Bhatia R. Imatinib mesylate (STI571) inhibits growth of primitive malignant progenitors in chronic myelogenous leukemia through reversal of abnormally increased proliferation. Blood. 2002;99:3792-800.

221. Angstreich GR, Matsui W, Huff CA, et al Effects of imatinib and interferon on primitive chronic myeloid leukaemia progenitors. Br J Haematol. 2005;130:373-81.

222. Pérez-Caro M, Sánchez-García I. Killing time for cancer stem cells (CSC): discovery and development of selective CSC inhibitors. Curr Med Chem. 2006;13:171925.

223. Kantarjian H, Giles F, Wunderle L, et al. Nilotinib in imatinib-resistant CML and Philadelphia chromosome-positive ALI. N Engl J Med. 2006;354:2542-51.

224. Talpaz M, Shah NP, Kantarjian H, et al. Dasatinib in imatinib-resistant Philadelphia chromosome-positive leukemias. N Engl J Med. 2006;354:2531-41.

225. Pasqualucci L, Neumeister P, Goossens T, et al. Hypermutation of multiple protooncogenes in B-cell diffuse large-cell lymphomas. Nature. 2001;412:341-6.

226. Hunger SP, Galili N, Carroll AJ, Crist WM, Link MP, Cleary ML. The $\mathrm{t}(1 ; 19)(\mathrm{q} 23 ; \mathrm{p} 13)$ results in consistent fusion of $\mathrm{E} 2 \mathrm{~A}$ and
PBX1 coding sequences in acute lymphoblastic leukemias. Blood. 1991;77:68793.

227. Willis TG, Zalcberg IR, Coignet LJ, et al. Molecular cloning of translocation $\mathrm{t}(1 ; 14)$ (q21;q32) defines a novel gene (BCL9) at chromosome 1q21. Blood. 1998; 91:187381.

228. Kramps T, Peter O, Brunner E, et al. Wnt/wingless signaling requires BCL9/ legless-mediated recruitment of pygopus to the nuclear beta-catenin-TCF complex. Cell. 2002;109:47-60.

229. Cariappa A, Liou HC, Horwitz BH, Pillai $\mathrm{S}$. Nuclear factor kappa B is required for the development of marginal zone B lymphocytes. J Exp Med. 2000;192:1175-82.

230. Chabot B, Stephenson DA, Chapman VM, Besmer P, Bernstein A. The proto-oncogene c-kit encoding a transmembrane tyrosine kinase receptor maps to the mouse W locus. Nature. 1988;335:88-9.

231. Kitamura Y, Hirotab S. Kit as a human oncogenic tyrosine kinase. Cell Mol Life Sci. 2004;61:2924-31.

232. Weisberg E, Boulton C, Kelly LM, et al. Inhibition of mutant FLT3 receptors in leukemia cells by the small molecule tyrosine kinase inhibitor PKC412. Cancer Cell. 2002;1:433-43.

233. Holmes ML, Carotta S, Corcoran LM, Nutt SL. Repression of Flt3 by Pax 5 is crucial for B-cell lineage commitment. Genes Dev. 2006;20:933-8. 